\title{
Water Quality, Organic Chemistry of Sediment, and Biological Conditions of Streams Near an Abandoned Wood-Preserving Plant Site at Jackson, Tennessee
}

By ARTHUR D. BRADFIELD, NANCY M. FLEXNER, and D.A. WEBSTER

U.S. GEOLOGICAL SURVEY

Water-Resources Investigations Report 93-4148

Prepared in cooperation with the U.S. Environmental Protection Agency Region IV, Waste Management Division North Superfund Remedial Branch 


\section{U.S. DEPARTMENT OF THE INTERIOR}

BRUCE BABBITT, Secretary

\section{U.S. GEOLOGICAL SURVEY}

ROBERT M. HIRSCH, Acting Director

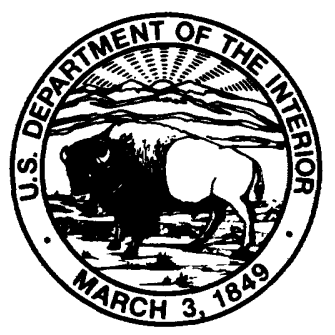

Any use of trade, product, or firm name in this report is for identification purposes only and does not constitute endorsement by the U.S.

Geological Survey.

For additional information write to:

District Chief

U.S. Geological Survey

810 Broadway, Suite 500

Nashville, Tennessee 37203
Copies of this report may be purchased from:

U.S. Geological Survey

Earth Science Information Center

Open-File Reports Section

Box 25286, MS 517

Denver Federal Center

Denver, Colorado 80225 


\section{CONTENTS}

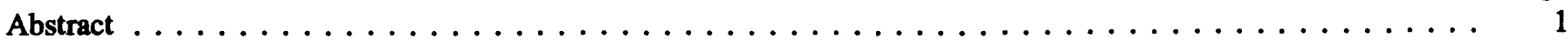

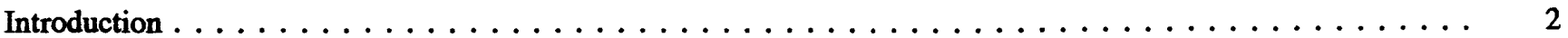

Purpose and scope ....................................

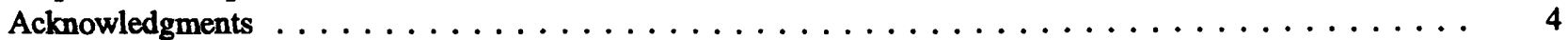

Description of sampling stations $\ldots \ldots \ldots \ldots$

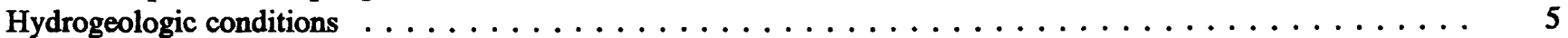

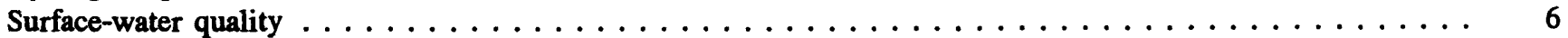

Inorganic chemistry of water $\ldots \ldots \ldots \ldots \ldots$

Organic chemistry of water $\ldots \ldots \ldots \ldots \ldots$

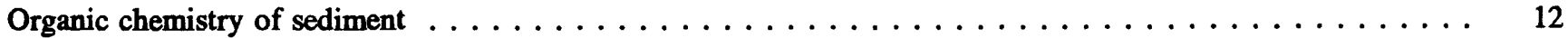

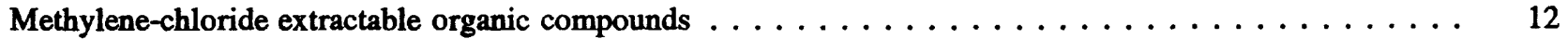

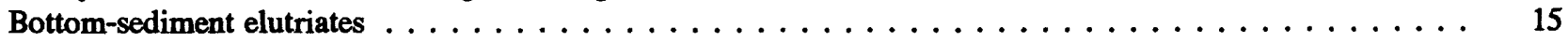

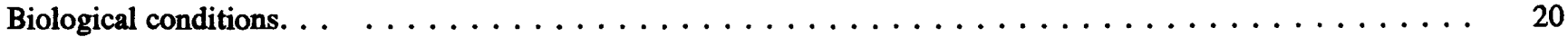

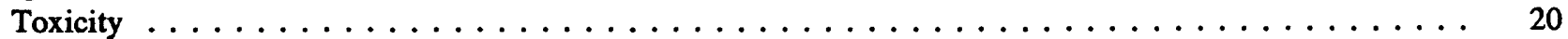

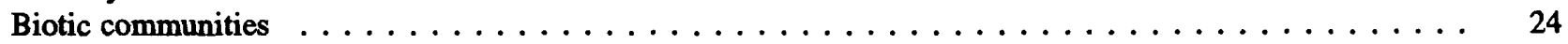

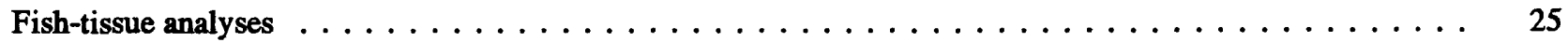

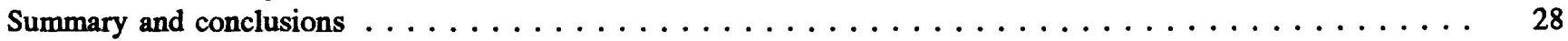

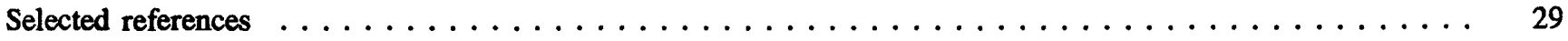

Appendix 1--Periphyton analyses of sampling stations

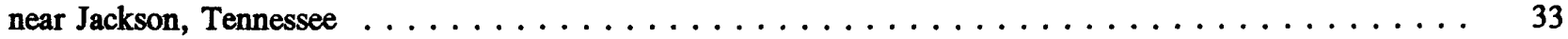

Appendix 2--Benthos and fish inventory for sampling

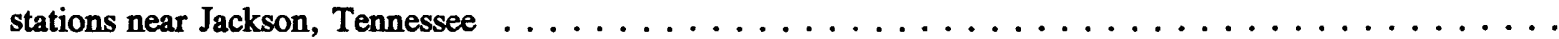

\section{FIGURES}

1. Map showing location of wood-preserving plant site and sampling stations near Jackson, Tennessee ...................................

2. Graphs showing selected properties of and constituents in water samples from streams near the abandoned wood-preserving plant site at Jackson,

Tennessee

\section{TABLES}

1. Description of sampling stations near the abandoned wood-preserving plant site at Jackson, Tennessee . . . . . . . . . . . . . . . . . . . . . . . . .

2. Particle size and organic content of stream-bed sediment collected from

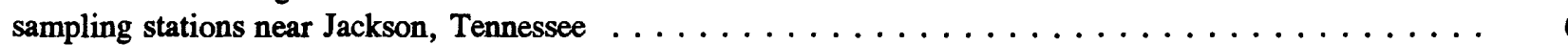

3. Inorganic water quality of streams near Jackson, Tennessee . . . . . . . . . . . . . . . . . .

4. Organic compounds for which surface-water samples were analyzed by gas chromatography/mass spectrometry . . . . . . . . . . . . . . . . . . . . . . . . . .

5. Volatile organic compounds detected in surface water near Jackson, Tennessee . . . . . . . . . . . . . .

6. Acid and base neutral extractable organic compounds detected in surface water near Jackson, Tennessee

7. Methylene-chloride extractable compounds for which sediment samples were analyzed by gas chromatography/mass spectrometry

8. Concentrations of methylene-chloride extractable compounds in bottom sediment and soil from stations near Jackson, Tennessee 
9. Volatile and semi-volatile water-extractable organic compounds for

which sediment elutriates were analyzed $\ldots \ldots \ldots \ldots \ldots \ldots \ldots \ldots \ldots \ldots \ldots$

10. Concentrations of volatile organic compounds detected in U.S. Geological

Survey whole water samples and U.S. Environmental Protection Agency

elutriates of sediment samples from streams near Jackson, Tennessee

11. Concentrations of semi-volatile extractable organic compounds from

U.S. Geological Survey sediment samples and U.S. Environmental

Protection Agency elutriates of sediment samples from streams near

Jackson, Tennessee . . . . . . . . . . . . . . . . . . . . . . .

12. Miscellaneous extractable organic compounds detected in elutriates

of sediment samples from steams near Jackson, Tennessee $\ldots \ldots \ldots \ldots \ldots \ldots \ldots \ldots$

13. Toxicity of water and of sediment samples from streams near Jackson,

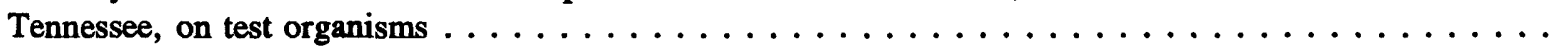

14. Relative abundance of periphyton species identified at surface-water

sampling stations near Jackson, Tennessee $\ldots \ldots \ldots \ldots \ldots \ldots \ldots \ldots \ldots \ldots \ldots \ldots$

15. Diversity of fish and benthic species identified at surface-water

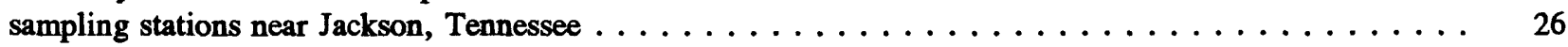

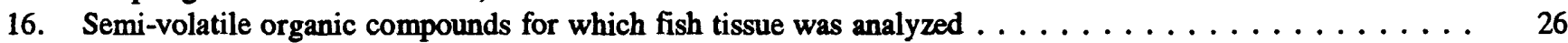

17. Organic compounds detected in tissue of fish near Jackson, Tennessee . . . . . . . . . . . . . 27

CONVERSION FACTORS, VERTICAL DATUM, AND ABBREVIATED WATER-QUALITY UNITS

\begin{tabular}{rll}
\hline Multiply & By & To obtain \\
\hline foot (ft) & 0.3048 & meter \\
foot per second (tt/s) & 0.3048 & meter per second \\
mile (mi) & 1.609 & kilometer \\
square mile (mi2) & 2.590 & square kilometer \\
acre & 0.4047 & hectare \\
inch (in.) & 25.4 & millimeter \\
micron $(\mu)$ & 0.001 & millimeter \\
& & \\
\hline
\end{tabular}

Sea level: In this report "sea level" refers to the National Geodetic Vertical Datum of 1929-a geodetic datum derived from a general adjustment of the first-order level nets of the United States and Canada, formerly called Sea Level Datum of 1929.

Water-quality units:

$\mathrm{mg} / \mathrm{L} \quad$ milligrams per liter

$\mu \mathrm{g} / \mathrm{L} \quad$ micrograms per liter

$\mu \mathrm{g} / \mathrm{kg} \quad$ micrograms per kilogram

$\mu \mathrm{S} / \mathrm{cm} \quad$ microsiemens per centimeter at 25 degrees Celsius

ntu nephelometric turbidity units 


\title{
Water Quality, Organic Chemistry of Sediment, and Biological Conditions of Streams Near an Abandoned Wood-Preserving Plant Site at Jackson, Tennessee
}

\author{
By Arthur D. Bradfield, Nancy M. Flexner, and D.A. Webster
}

\section{Abstract}

An investigation of the water quality, organic chemistry of sediment, and biological conditions of streams near an abandoned woodpreserving plant site at Jackson, Tennessee, was conducted by the U.S. Geological Survey during December 1990. The objectives of the study were to assess the extent of possible contamination of water and adverse affects on biota in the streams resulting from creosoterelated discharge originating at this Superfund site.

Central Creek, which forms the northern and western boundaries of the plant site, had the most pronounced degradation of water quality and biological conditions. The water sample from the most downstream station on Central Creek, CC-06, contained pentachlorophenol, a wood preservative, in a concentration of $30 \mu \mathrm{g} / \mathrm{L}$ (micrograms per liter), which exceeds the criterion maximum concentration of $9 \mu \mathrm{g} / \mathrm{L}$ for fish and aquatic life. The sample also contained $16 \mu \mathrm{g} / \mathrm{L}$ naphthalene, the most abundunt single constituent of coal tar used in creosote.

Bottom-sediment samples from stations on Central Creek contained 18 methylene-chloride extractable organic compounds. Concentrations of acenaphthene, naphthalene, and phenanthrene--creosote-related compounds--were higher at station CC-06 than at the other three upstream stations on Central Creek. Concentrations of these compounds ranged from 1,400 to $2,500 \mu \mathrm{g} / \mathrm{kg}$ (micrograms per kilogram), whereas concentrations in samples from background streams ranged from below detection limit to $80 \mu \mathrm{g} / \mathrm{kg}$. The concentration of naphthalene in the water-extractable bottomsediment elutriate sample from station CC-06 was $330 \mu \mathrm{g} / \mathrm{L}$, higher than at any other station.

Bottom-sediment samples from station FD-08 on the South Fork Forked Deer River, just downstream from its confluence with Central Creek, contained the highest concentrations of methylene-chloride extractable organic compounds of all stations sampled. Acenaphthene, anthracene, chrysene, fluoranthene, fluorene, pyrene, and phenanthrene were identified in concentrations ranging from 2,800 to $69,000 \mu \mathrm{g} / \mathrm{kg}$. Nine water-extractable organic compounds were detected in sedimentelutriate samples; concentrations ranged from an estimated 43 to $420 \mu \mathrm{g} / \mathrm{L}$. A possible reason for the high concentrations is that organic matter at station FD-08 comprised 11 percent of the bottom sediments, the largest percentage of all stations, providing greater potential capacity for the adsorption of organic compounds.

Exposure of test organisms to creosoterelated contaminants in the laboratory resulted in varying degrees of toxicity. Sedimentelutriate samples from station CC-06 caused 
slightly to highly toxic effects on Ceriodaphnia dubia (daphnia), Pimephalas promelas (fathead minnow), and Photobacterium phosphoreum (bacterium). Sediment-elutriate samples from station FD-08 were acutely toxic to $C$. dubia and $P$. promelas, and significantly toxic to $P$. phosphoreum and Selenastrum capricorutum (green algae).

Fish-tissue samples from station CC-06 contained concentrations of naphthalene, dibenzofuran, fluorene, and phenanthrene ranging from 1.5 to $3.9 \mu \mathrm{g} / \mathrm{kg}$. These compounds were not detected in fish-tissue samples from other stations.

Species composition and diversity of periphyton, benthos, and fish at stations on Central Creek indicated degraded environmental conditions. Blue-green algae at station CC-06 represented about 79 percent of the periphyton counted, whereas diatoms accounted for only 11 percent. Benthic invertebrate and fish samples from Central Creek had low diversity and population density. Most organisms identified are considered to be pollution tolerant.

Some of the adverse effects of creosoterelated contaminants on aquatic biota of the South Fork Forked Deer River might be mitigated by the large discharge and suspendedsediment loads of this stream. The presence of large concentrations of organic contaminants in the bottom sediment, however, still poses a substantial threat to the stream biota.

\section{INTRODUCTION}

American Creosote Works, Inc. (ACW) operated a facility for impregnating wood with preservatives near Jackson, Tennessee (fig. 1), from the early 1930's until December 1981. Most of the plant was dismantled and removed after the facility closed. The soils, ground water, and surface water near the site were heavily contaminated with woodpreserving chemicals, including creosote. In 1984, the abandoned plant site was designated a U.S. Environmental Protection Agency (USEPA) National Priorities List Superfund Site.

The 60-acre site is bounded by the South Fork Forked Deer River on the southwest and by Central Creek on the west and north. The Seaboard Railroad tracks are to the south and industrial property is to the east. Central Creek discharges to the South Fork Forked Deer near the southwestern corner of the site.

Until 1973, untreated process water and stormwater runoff from the facility were discharged directly into Central Creek. A levee was constructed in mid-1973 to retain surface-water runoff and to reduce the potential for flooding of the plant site area by the South Fork Forked Deer River. The soil borrow pits used to supply material for the levee construction were later used for sludge storage lagoons during site remediation.

A wastewater-treatment system was constructed during 1973-74 and operated until the facility closed in 1981. The treatment system consisted of oil/water separators, six sand filters, and a recirculation pond. The recirculation pond was reported to have overflowed on several occasions (Soil and Material Engineers, Inc., 1988). A detailed description of the site location, history, and extent of contamination is included in the remedial investigation report by Soil and Material Engineers, Inc. (1988).

Most of the contaminants associated with creosote in the wood-preserving process are organic compounds, including volatile organic compounds (VOC's), polynuclear aromatic hydrocarbons (PAH's), and phenols. Creosote is a complex mixture of PAH's and other aliphatic compounds obtained from petroleum-based oils. These aliphatic compounds are used to dilute creosote in the wood-preserving process. Many of these compounds are known or suspected carcinogens that can result in acute or chronic toxicity to organisms (Weiss, 1986).

Previous investigations were designed to define the extent of on-site contamination. Although a Remedial Investigation/Feasibility Study (RI/FS) was conducted for the USEPA, the investigation was limited to the wood-preserving plant site (Soil and Material Engineers, Inc., 1988). 


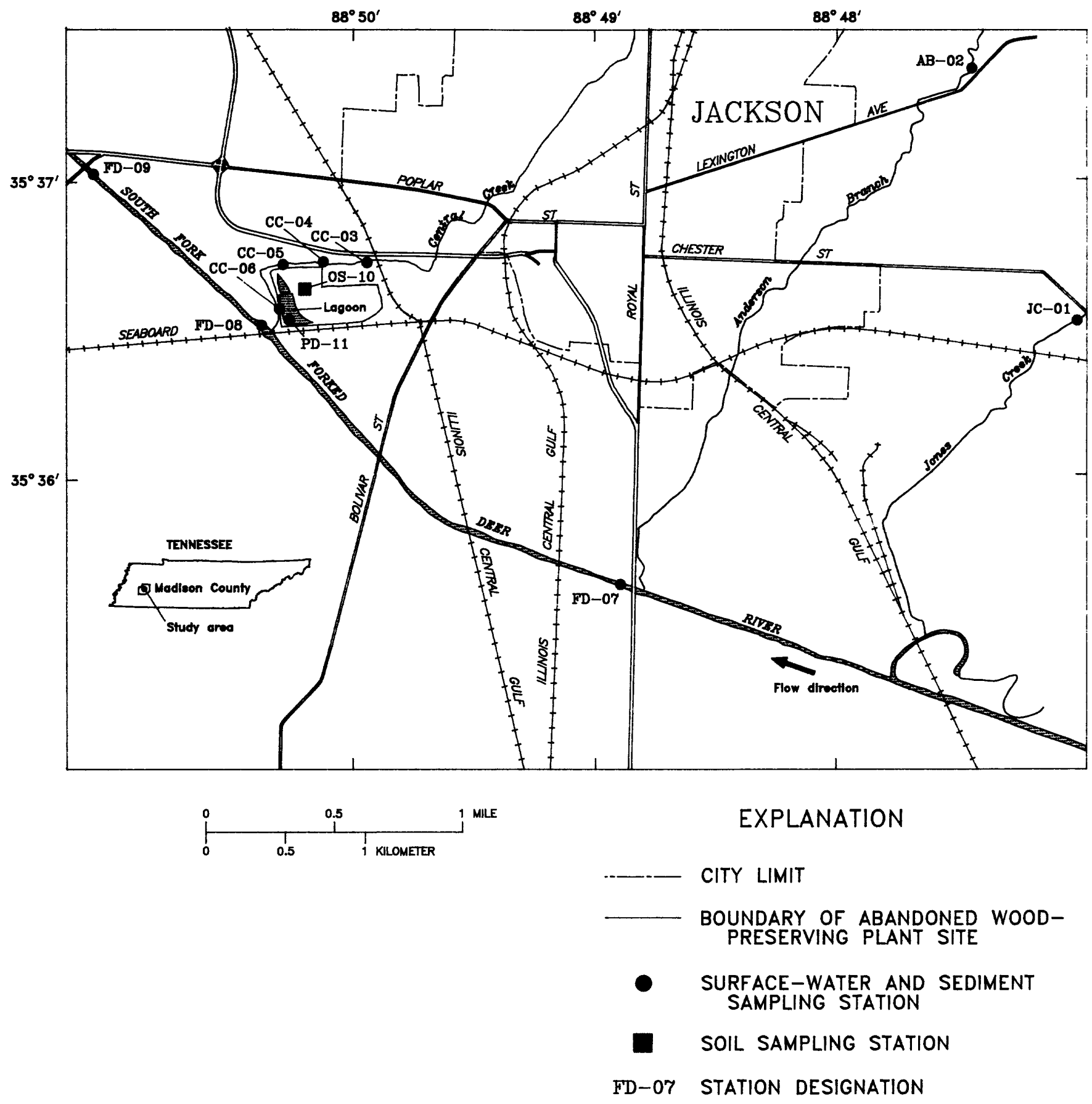

Figure 1. Location of wood-preserving plant site and sampling stations near Jackson, Tennessee 
Previous studies did not include an assessment of the extent to which nearby surface water, sediment, and biota are affected by contaminant migration. In 1990, the U.S. Geological Survey (USGS), in cooperation with the North Superfund Remedial Branch, Waste Management Division of the USEPA, Region IV, began a comprehensive investigation to determine the extent of off-site contamination and the toxicity of water and sediments from nearby surface waters.

\section{Purpose and Scope}

The objective of this report is to describe the water quality, organic chemistry of bottom sediment, and biological conditions of streams near the ACW plant site at Jackson, Tennessee. Towards this goal, the report summarizes the results of the investigation conducted by the USGS during December 1990. The study included collection of samples of water, sediment, and aquatic organisms from nearby streams that were potentially contaminated with creosote wastes. For comparison purposes, background samples were collected at stations on streams unaffected by creosote from the facility. The sampling included:

1. Water and bottom-sediment samples from nine stream stations.

2. Fish, benthic invertebrate, and algal samples at each stream station.

3. An on-site soil sample, and water and bottomsediment samples from a ditch draining a lagoon within the plant area.

Water and sediment samples were collected by USEPA and USGS staff. The samples were split on-site for delivery to the Environmental Services Division of the USEPA at Athens, Georgia, and the National Water Quality Laboratory of the USGS at Arvada, Colorado. Fish and benthic macroinvertebrate samples were collected and identified by James Gore, Center for Field Biology, Austin Peay State University, Clarksville, Tennessee. Analyses of fish tissue were conducted by ENSECO, Inc., Garden Grove, California, under contract with the USGS. Algal samples were collected by USGS staff and identified by Chadwick and Associates, Inc., Littleton, Colorado.

\section{Acknowledgments}

The authors gratefully acknowledge the assistance of Alan G. Auwarter and Phyllis Meyer, U.S. Environmental Protection Agency, Region IV, Athens, Georgia, and Todd Harris, James Maudsley, and Jay Glover of ManTech Environmental Technology, Inc., who provided water-quality and toxicity test data, shared in the preparation of many tables, and assisted in various other aspects of this study.

\section{Description of Sampling Stations}

The stations sampled for the investigation are near and within the abandoned wood-preserving plant site, in the general area of the plant site, and in areas near Jackson, Tennessee, that are believed to be unaffected by plant discharges (fig. 1 and table 1). The stations included:

- Two stations for background data, Jones Creek (JC-01) and Anderson Branch (AB-02). Both Jones Creek and Anderson Branch drain residential and mixed hardwood areas.

- Four stations on Central Creek that are on the north and west sides of the wood-preserving plant site. The stations are CC-03, upstream of the plant site; $\mathrm{CC}-04$ and $\mathrm{CC}-05$, adjacent to the plant site on the north; and $\mathrm{CC}-06$, adjacent to the plant site on the west and near the confluence of the creek with the South Fork Forked Deer River. Central Creek drains residential and industrial areas with little agricultural or forested land.

- Three stations on the South Fork Forked Deer River: station FD-07, located about $13 / 4$ miles upstream of the plant site; station FD-08, near the plant site and about 200 feet downstream of the confluence with Central Creek; and station FD-09, located about 1 mile downstream of the plant site (fig. 1). The South Fork Forked Deer River near the study area has a relatively large drainage area of approximately 500 square miles that consists primarily of agricultural land.

In addition to the surface-water stations, two sampling stations were established within the plant 
Table 1. Description of sampling stations near the abandoned wood-preserving plant site at Jackson, Tennessee

[>, greater than; -, not measured]

\begin{tabular}{|c|c|c|c|c|c|}
\hline $\begin{array}{c}\text { Station } \\
\text { name }\end{array}$ & $\begin{array}{c}\text { Station } \\
\text { number } \\
\text { (see figure 1) }\end{array}$ & $\begin{array}{l}\text { Width, } \\
\text { in feet }\end{array}$ & $\begin{array}{l}\text { Average } \\
\text { depth, } \\
\text { in feet }\end{array}$ & $\begin{array}{l}\text { Average } \\
\text { velocity, } \\
\text { in feet } \\
\text { per second }\end{array}$ & Comments \\
\hline Jones Creek & JC-01 & $8-10$ & 0.8 & 0.7 & Background station \\
\hline Anderson Branch & AB-02 & 15 & .6 & 1.4 & Background station \\
\hline Central Creek & $\mathrm{CC}-03$ & 4 & .3 & .4 & Upstream of wood-preserving plant site \\
\hline Central Creek & CC-04 & 4 & .5 & .6 & $\begin{array}{l}\text { Adjacent to wood-preserving plant site on } \\
\text { the north. }\end{array}$ \\
\hline Central Creek & $\mathrm{CC}-05$ & 4 & .7 & .2 & $\begin{array}{l}\text { Adjacent to wood-preserving plant site on } \\
\text { the north. }\end{array}$ \\
\hline Central Creek & CC-06 & 10 & .4 & .5 & $\begin{array}{l}\text { Adjacent to wood-preserving plant site on } \\
\text { the west. }\end{array}$ \\
\hline $\begin{array}{l}\text { South Fork Forked } \\
\text { Deer River. }\end{array}$ & FD-07 & 100 & $>1$ & .7 & $\begin{array}{l}\text { Upstream of confluence of Central Creek } \\
\text { with South Fork Forked Deer River. }\end{array}$ \\
\hline $\begin{array}{l}\text { South Fork Forked } \\
\text { Deer River. }\end{array}$ & FD-08 & 100 & $>1$ & .6 & $\begin{array}{l}\text { Downstream but near confluence of Centra } \\
\text { Creek with South Fork Forked Deer } \\
\text { River. }\end{array}$ \\
\hline $\begin{array}{l}\text { South Fork Forked } \\
\text { Deer River. }\end{array}$ & FD-09 & 100 & $>1$ & .8 & Downstream of wood-preserving plant site \\
\hline On-site & OS-10 & - & - & - & Soil sample, near buildings on-site \\
\hline $\begin{array}{l}\text { Lagoon discharge } \\
\text { station. }\end{array}$ & PD-11 & - & - & - & On-site discharge point \\
\hline
\end{tabular}

area. Station OS-10 is near the location of the main processing area when the plant was in operation. Soil samples were collected at OS-10 to determine the types of organic compounds present. A drainage ditch (PD-11) from holding lagoons near the western boundary of the site also was sampled for water and bottom-sediment chemistry.

\section{HYDROGEOLOGIC CONDITIONS}

The study area is located in the East Gulf Coastal Plain section of the Coastal Plain physiographic province (Fenneman, 1938, p. 81-83). Hydrogeologic units underlying the site are alluvium of Quaternary age and the Fort Pillow Sand of Tertiary age (Parks and Carmichael, 1989). These units are primarily sand with silty and clayey layers at various depths and comprise the alluvial and Fort Pillow aquifers in other areas of western Tennessee.

Ground-water flow at the wood-preserving plant site is primarily toward the South Fork Forked Deer River and the area near its confluence with Central Creek (Soil and Material Engineers, Inc., 1988). A slight upward potentiometric gradient exists within the aquifer underlying the former facility. Wells completed in the deeper sands have slightly higher water-level elevations than the shallower wells (Soil and Material Engineers, Inc., 1988). The upward gradient indicates that the plant-site area might be a discharge zone for the local and, possibly, the regional flow system. No water-level data from off-site areas north and west of Central Creek and south of the South Fork Forked Deer River are available to determine if additional ground water is discharging to the streams from these areas. 
The streams in the study area have low gradients, and the streambed substrate is primarily sand and silt with little gravel or clay (table 2). The particle-size distribution of bottom material from Central Creek ranged from primarily coarse- and medium-grained sand at the upstream station (CC-03) to primarily medium-grained sand and silt at the most downstream station (CC-06). The bottom material of the South Fork Forked Deer River downstream of the confluence with Central Creek (station FD-08) was composed largely of silt with a smaller amount of sand. Organic material in stream substrate samples amounted to about 3 percent or less of the total mass except for station FD-08, where organic material was about 11 percent of the sample (table 2).

Potential pathways for contaminants to be transported from the site to the surface-water system are in overland flow, through an on-site drainage ditch, and in ground water. Contaminated sediment in on-site holding ponds and contaminated soil particles may be carried as suspended sediment in surface flow. Contaminants in ground water discharged through stream beds to the streams could be sorbed by bottom sediment, particularly where the sediment contains a substantial amount of silt, clay, or organic material.

\section{SURFACE-WATER QUALITY}

The surface-water quality at the woodpreserving plant site and in unaffected areas was evaluated from samples collected from stations on Jones Creek, Anderson Branch, Central Creek, South Fork Forked Deer River, and the on-site lagoon drainage ditch. Samples were collected from December 10 to 12,1990 , when discharge in the streams represented base flow. The samples were analyzed by methods described by Skougstad and others (1979) for inorganic constituents and trace metals, and by methods described by Wershaw and others (1987) for volatile organic compounds and acid and base neutral extractable

Table 2. Particle size and organic content of stream-bed sediment collected from sampling stations near Jackson, Tennessee

[All units are percentage of total mass of sample; mm, millimeter; $\mu$, micron]

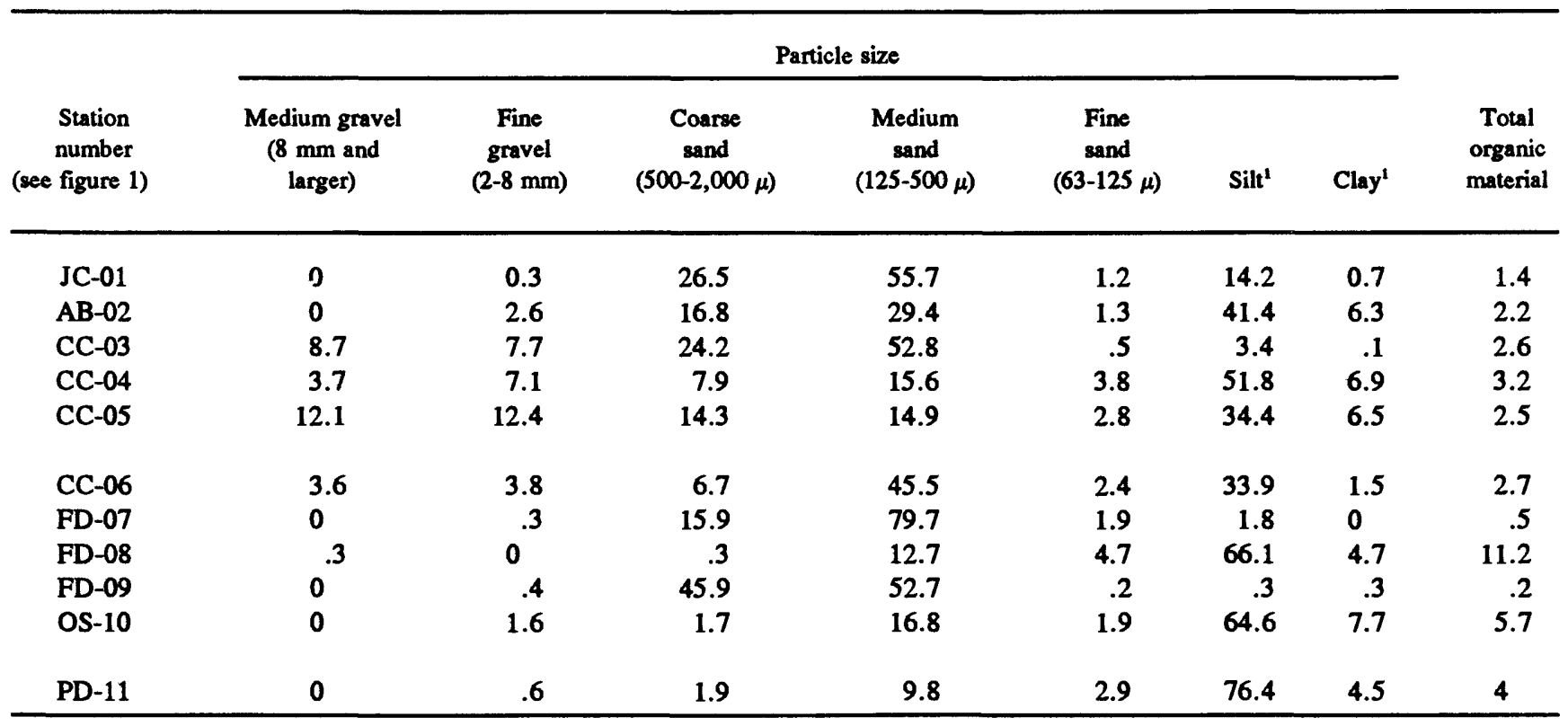

'Particles less than 63 microns in diameter were centrifuged. The bottom fraction was classified as silt; the top fraction, as clay. 
organic compounds. Field determinations were made of specific conductance, $\mathrm{pH}$, temperature, and alkalinity.

Reporting levels are given in the tabular data for most of the organic compounds identified in samples submitted to the USGS laboratory. A reporting level is the lowest measured concentration of a constituent that may be reliably reported using a given analytical method. Due to unpredictable matrix effects on detection limits, the reporting level is set somewhat higher than the detection limit.

\section{Inorganic Chemistry of Water}

The inorganic chemistry of the streams sampled was similar to that of other streams in the western Tennessee part of the Coastal Plain province. Concentrations of major ions and trace elements in the surface-water samples reflect the geology of the study area, land use, and the effects of the abandoned wood-preserving plant site. Typically, streams in the area have low concentrations of dissolved solids, major anions and major cations; low alkalinity; and neutral to slightly basic $\mathrm{pH}$.

The water sample from Jones Creek had a low specific-conductance $(57 \mu \mathrm{S} / \mathrm{cm})$, neutral $\mathrm{pH}(7.0)$, and low concentrations of dissolved chloride $(4.9 \mathrm{mg} / \mathrm{L})$, sulfate $(2.2 \mathrm{mg} / \mathrm{L})$, other major constituents, and trace elements (table 3). Although the sample from Anderson Branch had a higher specific conductance $(115 \mu \mathrm{S} / \mathrm{cm})$ and $\mathrm{pH}(7.7)$, concentrations of dissolved chloride $(5.4 \mathrm{mg} / \mathrm{L})$, sulfate $(3.1 \mathrm{mg} / \mathrm{L})$, and trace elements were low (table 3) and were similar to those determined for Jones Creek.

Inorganic chemical characteristics of water samples from the South Fork Forked Deer River were similar to samples from Jones Creek and Anderson Branch. Samples from the South Fork Forked Deer had low specific conductance $(53-60 \mu \mathrm{S} / \mathrm{cm})$, and low concentrations of dissolved chloride (3.3-3.9 $\mathrm{mg} / \mathrm{L})$ and sulfate $(4.8-5.3 \mathrm{mg} / \mathrm{L})$. Concentrations of other inorganic constituents were similar to those in samples from Jones Creek and Anderson Branch (table 3).

Water samples from Central Creek had higher specific-conductance values and concentrations of most inorganic constituents than samples from these other streams (table 3 and fig. 2). Specificconductance values ranged from 348 to $465 \mu \mathrm{S} / \mathrm{cm}$, about three to nine times the values measured in samples from other streams of the area. Concentrations of dissolved calcium (44-55 $\mathrm{mg} / \mathrm{L}$ ), chloride (13-41 $\mathrm{mg} / \mathrm{L})$, sulfate $(35-40 \mathrm{mg} / \mathrm{L})$, barium (79-110 $\mu \mathrm{g} / \mathrm{L})$, strontium $(180-210 \mu \mathrm{g} / \mathrm{L})$, and other inorganic constituents also were higher in samples from Central Creek than in samples from the other streams (table 3).

In addition, values for several properties and many constituents increased downstream along Central Creek. This increase over a short reach of stream indicates that contaminated ground water discharges from the wood-preserving plant site to the stream. Specific-conductance values increased from 348 to $465 \mu \mathrm{S} / \mathrm{cm}$, and dissolved solids increased from 204 to $262 \mathrm{mg} / \mathrm{L}$. The dissolvedchloride concentration increased to $41 \mathrm{mg} / \mathrm{L}$ at CC-06, more than three times the concentration $(13 \mathrm{mg} / \mathrm{L})$ at station CC-03 upstream. Following a similar trend, concentrations of dissolved calcium increased from 44 to $55 \mathrm{mg} / \mathrm{L}$; magnesium, from 5.8 to $7.7 \mathrm{mg} / \mathrm{L}$; sodium, from 15 to $27 \mathrm{mg} / \mathrm{L}$; barium, from 79 to $110 \mu \mathrm{g} / \mathrm{L}$; iron, from 46 to $4,200 \mu \mathrm{g} / \mathrm{L}$; manganese, from 280 to $1,400 \mu \mathrm{g} / \mathrm{L}$; and strontium, from 180 to $210 \mu \mathrm{g} / \mathrm{L}$ (table 3).

Although the water sample collected from the lagoon discharge ditch (PD-11) had a higher dissolved-sulfate concentration $(57 \mathrm{mg} / \mathrm{L})$ than the water sample from station CC- $06(35 \mathrm{mg} / \mathrm{L})$ nearby, concentrations of most other constituents were lower. Concentrations of chloride $(7.8 \mathrm{mg} / \mathrm{L})$, iron $(220 \mu \mathrm{g} / \mathrm{L})$, manganese $(220 \mu \mathrm{g} / \mathrm{L})$, and sodium $(3.2 \mathrm{mg} / \mathrm{L})$ were relatively low in the discharge from the lagoon compared to samples from Central Creek. Water chemistry of the lagoon appears to be dominated by rainfall and runoff, whereas water chemistry of Central Creek is more affected by ground-water discharge. 


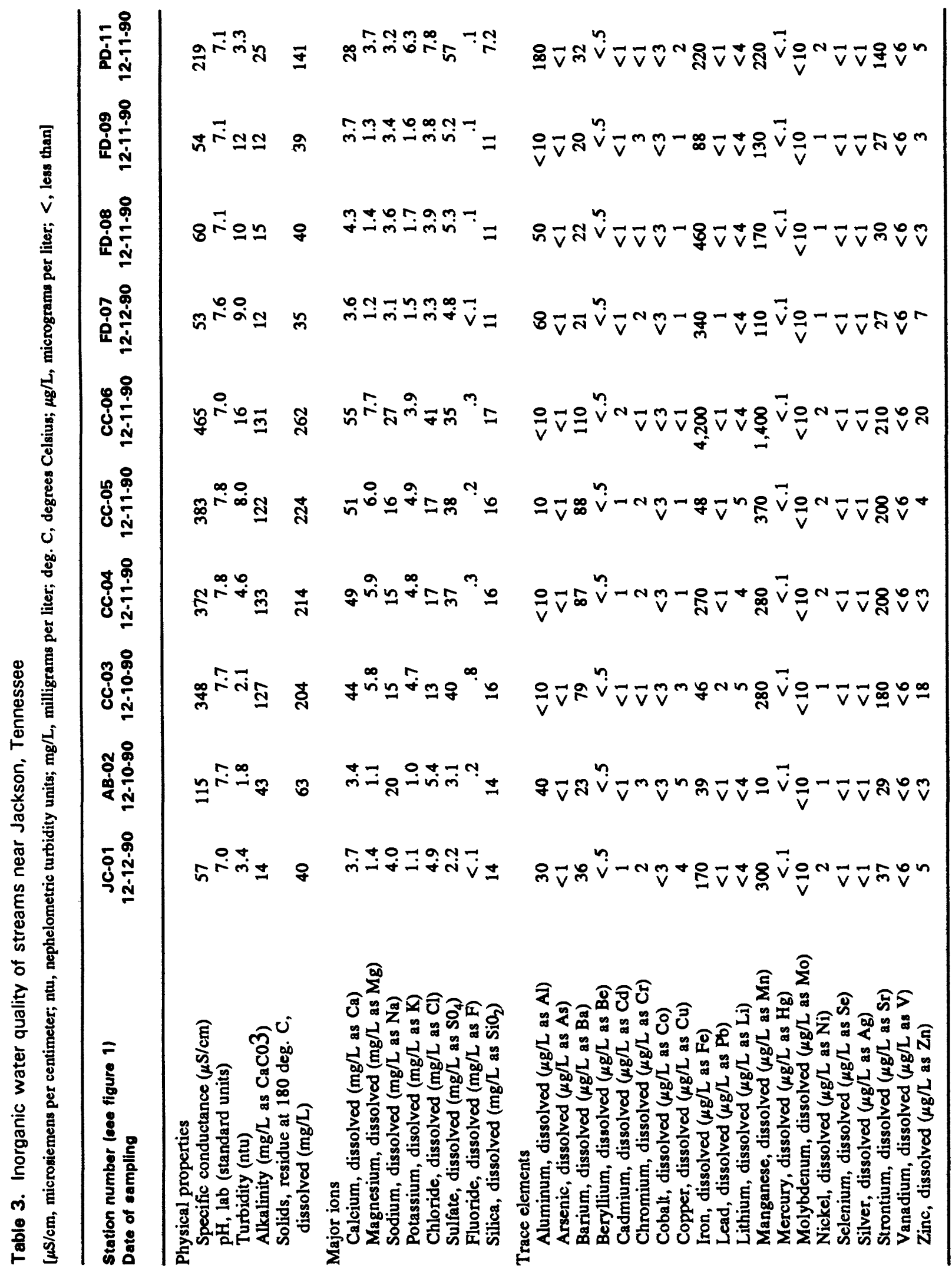



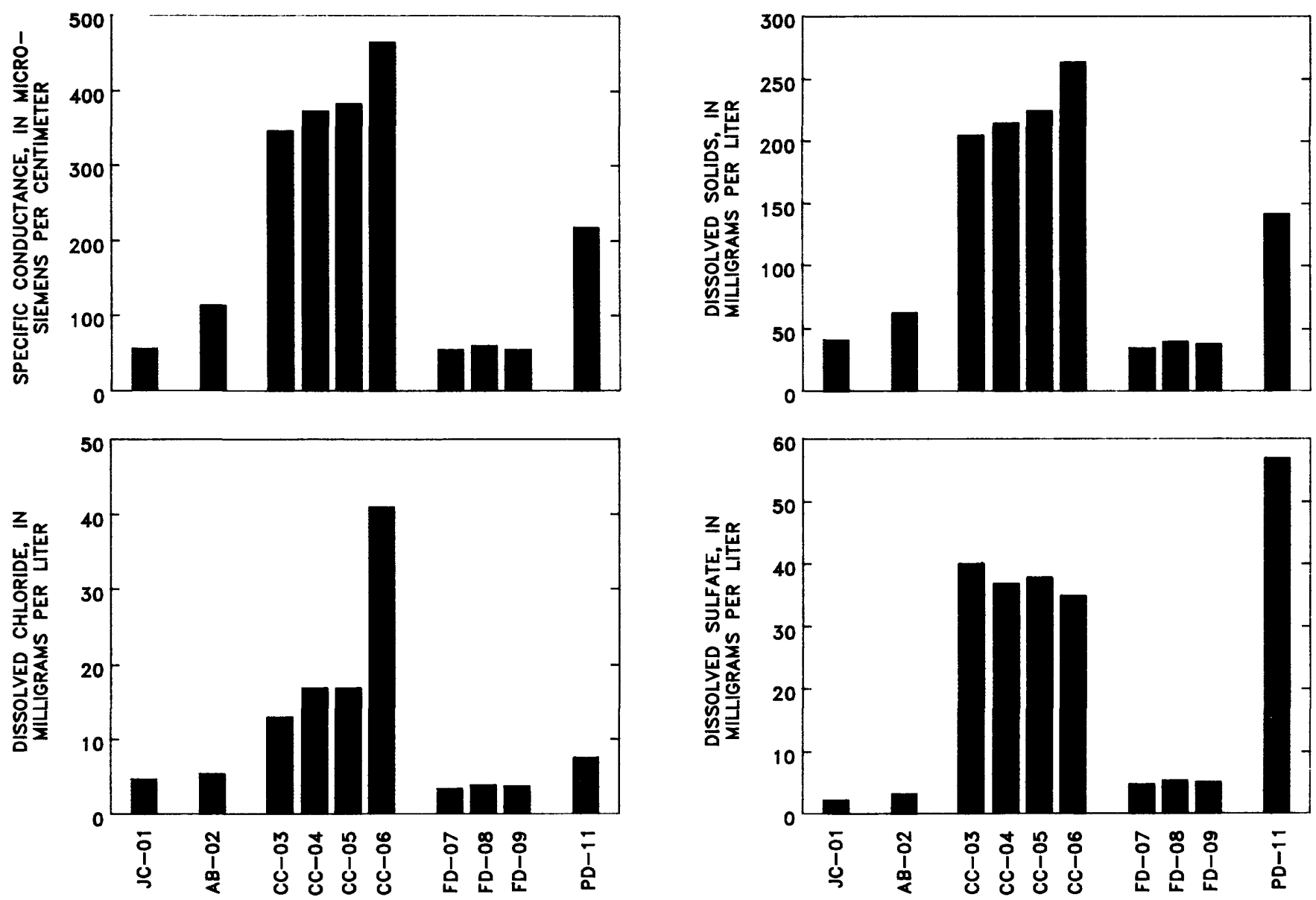

EXPLANATION

SAMPLING STATIONS

JC JONES CREEK

AB ANDERSON BRANCH

CC CENTRAL CREEK
FD SOUTH FORK FORKED DEER RIVER

PD DRAINAGE DITCH

Note: See table 1 for detalled station description

Figure 2. Selected properties of and constituents in water samples from streams near the abandoned woodpreserving plant site at Jackson, Tennessee

\section{Organic Chemistry of Water}

Water samples collected from 10 stations were analyzed for volatile, acid extractable, and base neutral extractable organic compounds (table 4). Many of these compounds commonly are contained in creosote used in the wood-preserving operation (Soil and Material Engineers, Inc., 1988). For brevity, the subsequent analytical tables show only the compounds detected at each station.

Volatile organic compounds were detected only in the water samples from stations $\mathrm{CC}-06$ and 
Table 4. Organic compounds for which surface-water samples were analyzed by gas chromatography/mass spectrometry

Volatile organic compounde

Benzene

Bromobenzene

Bromodichloromethane

Bromoform

Bromomethane

Carbon tetrachloride

Chlorobenzene

Chloroethane

Chloroethyl vinyl ether

Chloroform

Chloromethane

2-Chlorotoluene

4-Chlorotoluene

Dibromochloromethane

Dibromomethane

1,2-Dibromoethane

4-Chloro-3-methylphenol

2-Chlorophenol

2,4-Dichlorophenol

2,4-Dimethylphenol
1,2-Dichlorobenzene

1,3-Dichlorobenzene

1,4-Dichlorobenzene

Dichlorodifluoromethane

1,1-Dichloroethane

1,2-Dichloroethane

1,1-Dichloroethene

1,2-Dichloroethene

Dichloromethane

1,2-Dichloropropane

1,3-Dichloropropane

2,2-Dichloropropane

1,1-Dichloropropene

cis-1,3-Dichloropropene

trans-1,3-Dichloropropene

Ethylbenzene

Semi-volatile acid extractable compounds

2,4-Dinitrophenol

4,6-Dinitro-2-methylphenol

2-Nitrophenol

4-Nitrophenol
Methyl bromide

Methylene chloride

Styrene

1,1,1,2-Tetrachloroethane

1,1,2,2-Tetrachloroethane

Tetrachloroethene

Toluene

1,1,1-Trichloroethane

1,1,2-Trichloroethane

Trichloroethene

Trichlorofluoromethane

1,2,3-Trichloropropane

Vinyl chloride

Xylenes, total
Semi-volatile base neutral extractable compounds
Acenaphthene
Acenaphthylene
Anthracene
Benzo (a) anthracene
Benzo (b) fluoranthene
Benzo (k) fluoranthene
Benzo $(g, h, i)$ perylene
Benzo (a) pyrene
4-Bromophenylphenylether
Butylbenzylphthalate
bis (2-Chloroethoxy) methane
bis (2-Chloroethyl) ether
bis (2-Chloroisopropyl) ether
2-Chloronaphthalene
4-Chlorophenylphenylether

Chrysene

Dibenzo $(\mathrm{a}, \mathrm{h})$ anthracene

1,2-Dichlorobenzene

1,3-Dichlorobenzene

1,4-Dichlorobenzene

Diethylphthalate

Dimethylphthalate

Di-n-butylphthalate

2,4-Dinitrotoluene

2,6-Dinitrotoluene

Di-n-octylphthalate

bis (2-Ethylhexyl) phthalate

Fluoranthene

Fluorene

Hexachlorobenzene
Hexachlorobutadiene

Hexachlorocyclopentadiene

Hexachloroethane

Indeno $(1,2,3-c, d)$ pyrene

Isophorone

Naphthalene

Nitrobenzene

n-Nitroso-di-n-propylamine

n-Nitrosodiphenylamine

n-Nitroso-n.n-dimethylamine

Phenanthrene

Pyrene

1,2,4-Trichlorobenzene 
FD-08. Concentrations of the VOC's detected in the station CC-06 sample ranged from 0.2 to $12 \mu \mathrm{g} / \mathrm{L}$ (table 5). Most of these compounds also were detected in ground water at the plant site during a previous investigation (Soil and Material Engineers, Inc., 1988). The presence of VOC's in ground water beneath the plant site and in surface water at $\mathrm{CC}-06$ provides further evidence of the discharge of contaminated ground water from the plant site to Central Creek. Naphthalene $(0.5 \mu \mathrm{g} / \mathrm{L})$, which may be reported as a VOC and also as a semi-volatile organic compound, was the only VOC detected in water from FD-08.

Acid and base neutral extractable organic compounds were detected in water from Central Creek at station $\mathrm{CC}-06$, discharge from the lagoon (station PD-11), and in the South Fork Forked Deer (station FD-08) near its junction with Central Creek (fig. 1). Thirteen of these organic compounds were detected at $\mathrm{CC}-\mathrm{O} 6$ in concentrations ranging from
0.05 to $30 \mu \mathrm{g} / \mathrm{L}$ (table 6). Concentrations reported for 9 of the 13 compounds were sufficient for identification of the compound, but were too low for accurate quantification, and are considered estimated concentrations. The presence of naphthalene $(16 \mu \mathrm{g} / \mathrm{L})$, the most abundant single constituent of coal tar used in creosote (Merck and Co., Inc., 1983, p. 914), and pentachlorophenol (30 $\mu \mathrm{g} / \mathrm{L})$, a wood preservative, imply the quality of surface water at station CC-06 has been degraded by past activities at the plant site. The pentachlorophenol concentration of $30 \mu \mathrm{g} / \mathrm{L}$ exceeds the water quality criterion maximum concentration (CMC) established by the Tennessee Department of Environment and Conservation (1991) for fresh-water fish and aquatic life. The freshwater aquatic-life CMC for pentachlorophenol is expressed as a function of $\mathrm{pH}$. At a $\mathrm{pH}$ of 7.0, the value reported at $\mathrm{CC}-06$, the CMC limit for pentachlorophenol is $9 \mu \mathrm{g} / \mathrm{L}$.

Table 5. Volatile organic compounds detected in surface water near Jackson, Tennessee

[Concentrations in micrograms per liter; <, less than]

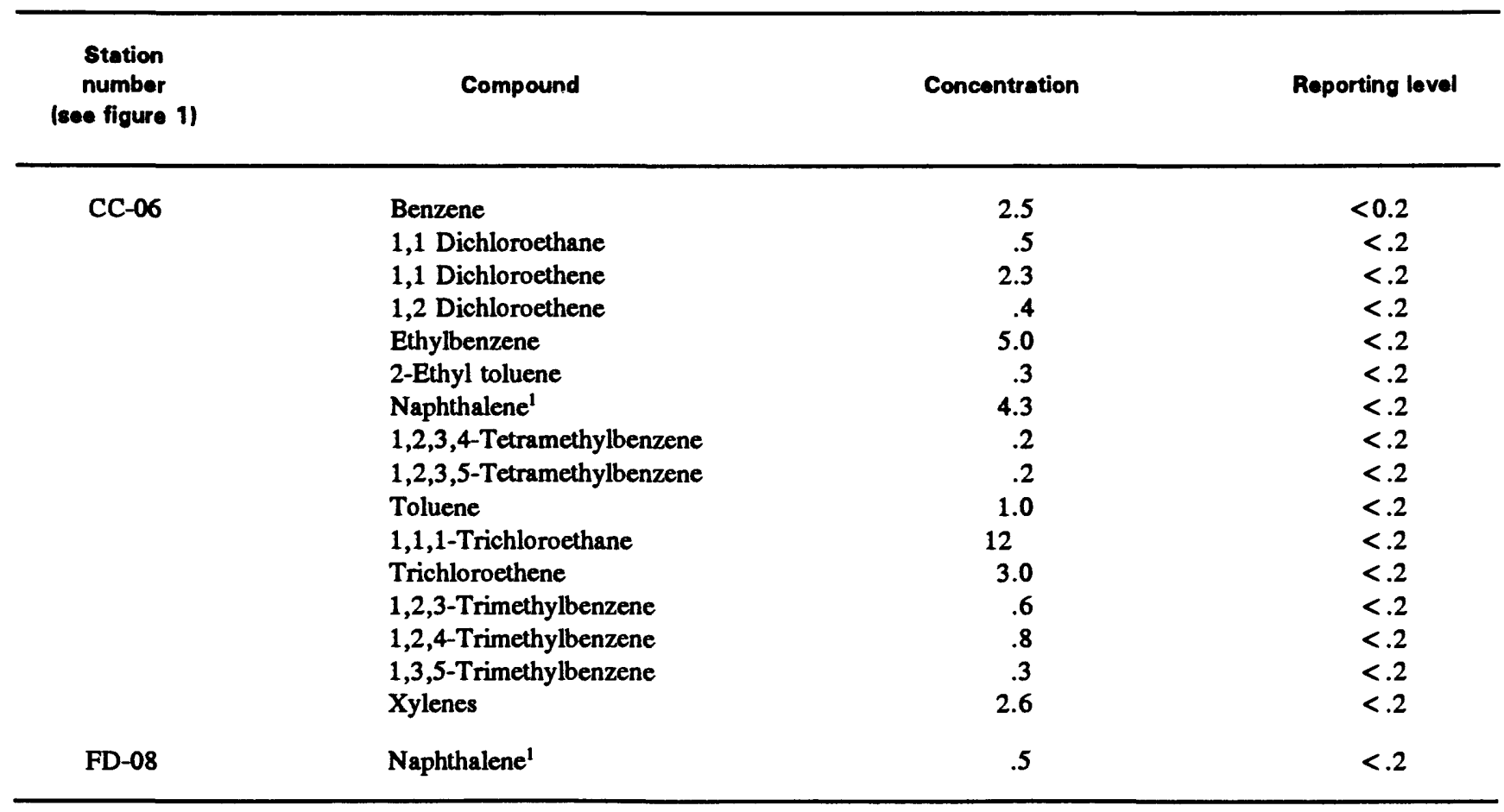

${ }^{1}$ Naphthalene may be reported as a volatile organic compound and also as a semi-volatile organic compound. 
Table 6. Acid and base neutral extractable organic compounds detected in surface water near Jackson, Tennessee [Concentrations in micrograms per liter; <, less than; ', estimated value--compound identified, but concentration too low to quantify accurately]

\begin{tabular}{|c|c|c|c|}
\hline $\begin{array}{c}\text { Station } \\
\text { number } \\
\text { [ece figure 1) }\end{array}$ & Compound & Concentration & Reporting lovel \\
\hline \multirow[t]{13}{*}{ CC-06 } & Acenaphthene & 15.0 & $<5$ \\
\hline & Acenaphthylene & $.38 \mathrm{~J}$ & $<5$ \\
\hline & Anthracene & $.15^{\mathrm{J}}$ & $<5$ \\
\hline & 2,4-Dichlorophenol & $.30^{\mathrm{J}}$ & $<5$ \\
\hline & 2,4-Dimethylphenol & $1.4 \mathrm{~J}$ & $<5$ \\
\hline & Fluoranthene & $.10^{\mathrm{J}}$ & $<5$ \\
\hline & Fluorene & 6.0 & $<5$ \\
\hline & Naphthalene & 16 & $<5$ \\
\hline & 2-Nitrophenol & $.32 \mathrm{~J}$ & $<5$ \\
\hline & Pentachlorophenol & 30 & $<30$ \\
\hline & Phenanthrene & $1.4^{\mathrm{J}}$ & $<5$ \\
\hline & Pyrene & $.05^{\mathrm{J}}$ & $<5$ \\
\hline & 2,4,6-Trichlorophenol & $5.5 \mathrm{~J}$ & $<20$ \\
\hline \multirow[t]{2}{*}{ PD-11 } & Anthracene & $.06^{\mathrm{J}}$ & $<5$ \\
\hline & Pentachlorophenol & $1.2^{\mathrm{J}}$ & $<30$ \\
\hline \multirow[t]{2}{*}{ FD-08 } & Acenaphthene & $.23 \mathrm{~J}$ & $<5$ \\
\hline & Naphthalene & $.75^{\mathrm{J}}$ & $<5$ \\
\hline
\end{tabular}

Anthracene and pentachlorophenol were detected in the lagoon discharge at station PD-11. The estimated concentrations were 0.06 and $1.2 \mu \mathrm{g} / \mathrm{L}$, respectively (table 6). Acenaphthene and naphthalene also were detected in water from FD-08 at estimated concentrations of 0.23 and $0.75 \mu \mathrm{g} / \mathrm{L}$, respectively.

\section{ORGANIC CHEMISTRY OF SEDIMENT}

Samples of bottom sediment were collected from riffles and pools at the nine stations on streams near the wood-preserving plant site and in areas unaffected by the plant. A bottom-sediment sample from the ditch draining the lagoons and one soil sample from OS-10 also were collected. The sediment and soil samples were analyzed for methylene-chloride extractable organic compounds by the National Water Quality Laboratory of the USGS, using procedures described by Wershaw and others (1987). The sediment samples were split onsite with USEPA personnel to obtain comparable samples to assess the toxicity to test organisms and to conduct chemical analyses of water elutriates.

\section{Methylene-Chloride Extractable Organic Compounds}

Analyses were made for 54 methylene-chloride extractable organic compounds, including those compounds commonly associated with creosote and creosote waste products, in the sediment and soil samples (table 7). Five of these 54 compounds were detected at Jones Creek and 10 compounds were detected at Anderson Branch (table 8). Most 
Table 7. Methylene-chloride extractable compounds for which sediment samples were analyzed by gas chromatography/mass spectrometry

[Reporting levels are conatituent apecific and range from 200 to 600 micrograms per kilogram]

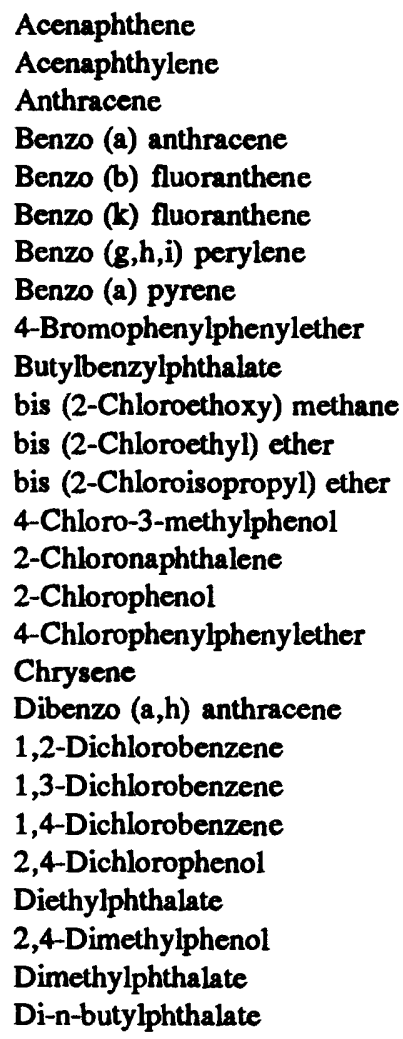

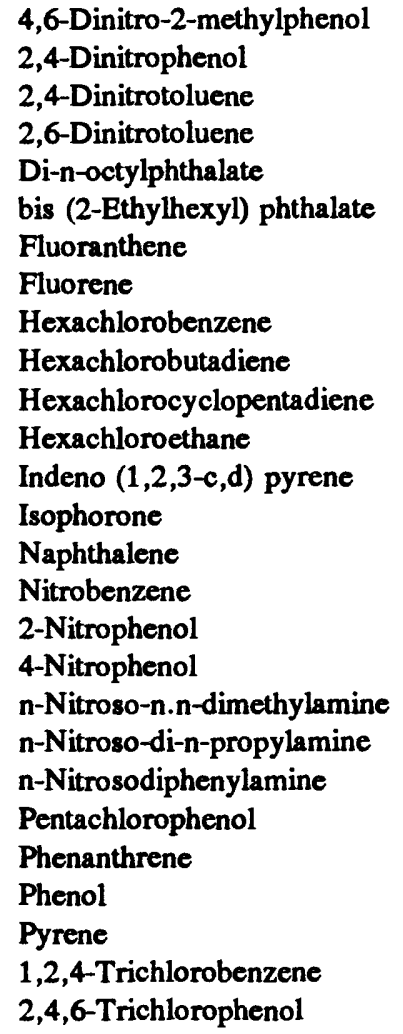

compounds detected in sediment samples from Jones Creek and Anderson Branch were in concentrations too low to quantify accurately.

A total of 18 methylene-chloride extractable organic compounds was detected in samples from stations on Central Creek. The number of compounds detected in each sample ranged from 12 to 17 (table 8). Concentrations of many organic compounds were higher in the sample from $\mathrm{CC}-03$ (the upstream station) than in samples from $\mathrm{CC}-04$ and $\mathrm{CC}-05$. The highest concentrations of most compounds were in the sample from $\mathrm{CC}-06$, the most downstream station. Compounds in large concentrations at $\mathrm{CC}-06$ included naphthalene $(2,500 \mu \mathrm{g} / \mathrm{kg})$, phenanthrene $(1,400 \mu \mathrm{g} / \mathrm{kg})$, and acenaphthene $(1,400 \mu \mathrm{g} / \mathrm{kg})$.
Bottom-sediment samples from stations FD-07 and FD-09 on the South Fork Forked Deer River had low concentrations of acenapthylene and naphthalene, respectively. Other methylenechloride extractable organic compounds may have been present in samples from these stations, but if so, the probable small concentrations could have been reduced below the level of detection by the deposition of large amounts of sediment from agricultural activities upstream. The concentrations of organic contaminants in sediment samples from stations FD-07 and FD-09 and from stations JC-01 and $\mathrm{AB}-02$ on the two background streams were small compared to concentrations in sediment samples from Central Creek. 


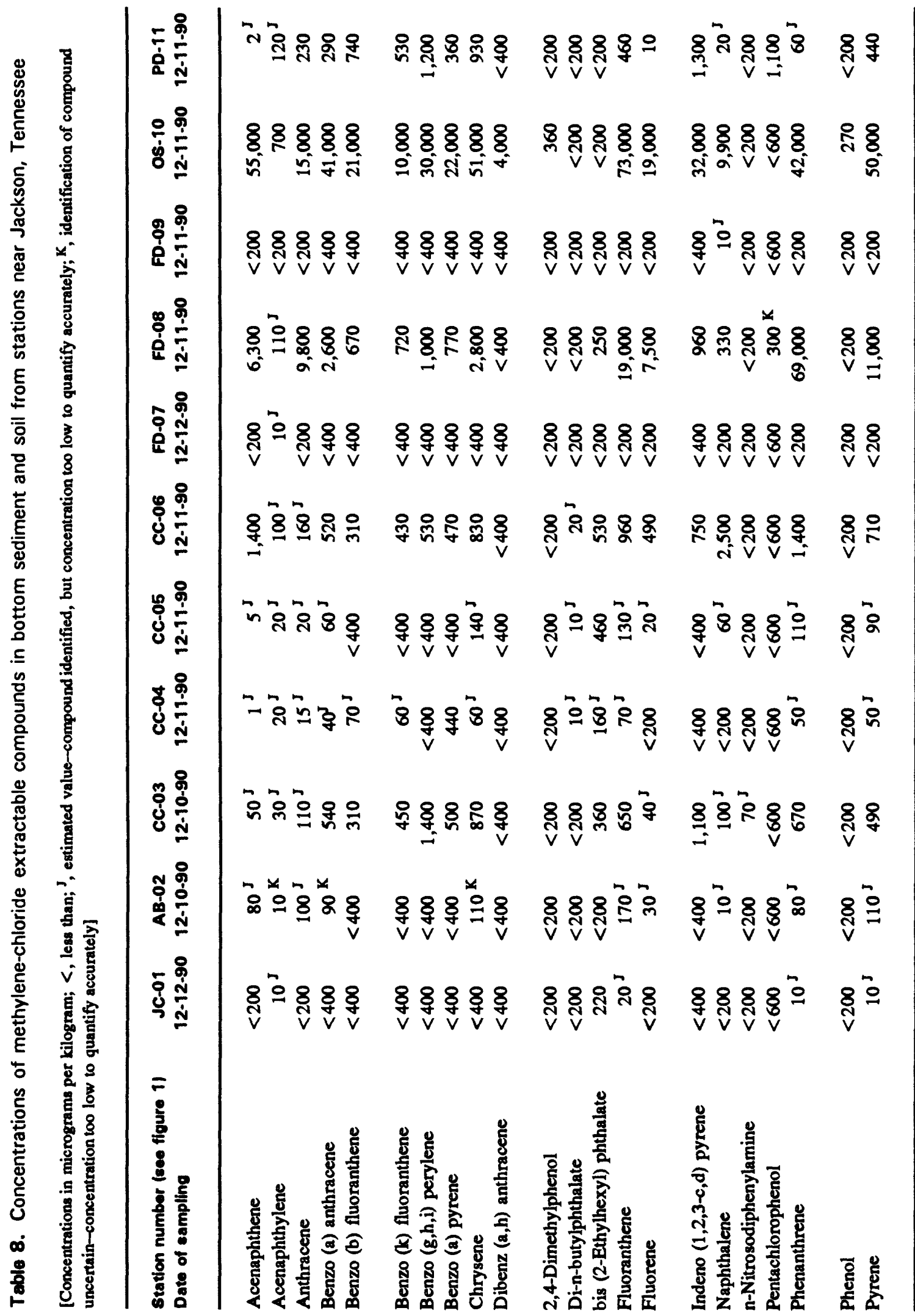


The presence of these contaminants in the outlying areas may be attributed to the ubiquitous nature of these compounds in the environment. Coal tar products, such as creosote, are used to preserve telephone poles, railroad ties, and pilings for many bridges throughout western Tennessee, and are transported in trace concentrations in surface runoff to local streams. Runoff from asphalt pavement, common in most industrial and residential areas, also can contribute these organic compounds to streams.

In contrast to the sediment samples from stations FD-07 and FD-09 on the South Fork Forked Deer River, the sediment sample from FD-08 contained 17 methylene-chloride extractable organic compounds. Concentrations of most of these compounds were higher in the sample from FD-08 than in the samples from all other stations on streams in the study area, and were exceeded only by those of the soil sample collected at the facility. Large concentrations of acenaphthene $(6,300 \mu \mathrm{g} / \mathrm{kg})$, anthracene $(9,800 \mu \mathrm{g} / \mathrm{kg})$, chrysene $(2,800 \mu \mathrm{g} / \mathrm{kg})$, fluoranthene $(19,000 \mu \mathrm{g} / \mathrm{kg})$, fluorene $(7,500 \mu \mathrm{g} / \mathrm{kg})$, phenanthrene $(69,000 \mu \mathrm{g} / \mathrm{kg})$, pyrene $(11,000 \mu \mathrm{g} / \mathrm{kg}$ ), and benzo (a) anthracene $(2,600 \mu \mathrm{g} / \mathrm{kg})$ were measured in the sediment sample from FD-08. The percentage of organic matter was highest in the sediment from this station (11 percent, table 2), possibly providing greater potential for the adsorption of organic compounds.

The soil sample collected on-site (OS-11) contained many contaminants that were detected in adjacent streams. A total of 18 compounds were identified, three of which were detected only in the sample from this station. Concentrations of most compounds were very high: acenaphthene $(55,000 \mu \mathrm{g} / \mathrm{kg})$, anthracene $(15,000 \mu \mathrm{g} / \mathrm{kg})$, benzo (a) anthracene $(41,000 \mu \mathrm{g} / \mathrm{kg})$, benzo (b) fluoranthene $(21,000 \mu \mathrm{g} / \mathrm{kg})$, benzo (k) fluoranthene $(10,000 \mu \mathrm{g} / \mathrm{kg})$, benzo (a) pyrene $(22,00 \mu \mathrm{g} / \mathrm{kg})$, benzo $(\mathrm{g}, \mathrm{h}, \mathrm{i})$ perylene $(30,000 \mu \mathrm{g} / \mathrm{kg})$, chrysene $(51,000 \mu \mathrm{g} / \mathrm{kg})$, fluoranthene $(73,000 \mu \mathrm{g} / \mathrm{kg})$, fluorene $(19,000 \mu \mathrm{g} / \mathrm{kg})$, indeno $(1,2,3-\mathrm{c}, \mathrm{d})$ pyrene $(32,000 \mu \mathrm{g} / \mathrm{kg})$, naphthalene $(9,900 \mu \mathrm{g} / \mathrm{kg})$, phenanthrene $(42,000 \mu \mathrm{g} / \mathrm{kg})$, and pyrene $(50,000 \mu \mathrm{g} / \mathrm{kg})$.
Twelve methylene-chloride extractable organic compounds were identified in the bottom-sediment samples from the ditch draining the holding lagoons (PD-11). Of the 12 compounds, 5 were present in somewhat lower concentrations than at $\mathrm{CC}-06$, and 5 were present in higher concentrations. Two compounds identified in the PD-11 sample were not detected in the $\mathrm{CC}-06$ sample. One of those compounds was pentachlorophenol $(1,100 \mu \mathrm{g} / \mathrm{kg})$, which was detected at PD-11 only.

\section{Bottom-Sediment Elutriates}

The bottom-sediment samples also were analyzed by the USEPA to determine concentrations of organic compounds that could be extracted with water. Chemical analysis of the elutriates identified those compounds that would likely be released into surface water and consequently could pose a threat to aquatic biota. The analyses also provided information related to the results of toxicity tests. The bottom-sediment elutriates were analyzed for 51 VOC's, 50 of the 54 semi-volatile organic compounds analyzed by the methylene-chloride extraction procedures, 13 additional semi-volatile organic compounds (table 9), and miscellaneous extractable organic compounds. An elutriate of the soil sample collected at the facility was not prepared.

Relatively few organic compounds were identified in the elutriate samples using water as the extraction medium, and concentrations of most compounds were small relative to concentrations extracted with methylene chloride. Concentrations of VOC's identified in whole water samples and in water-extractable bottom-sediment elutriates are listed in table 10, and concentrations of methylenechloride extractable semi-volatile organic compounds and water-extractable elutriates of bottomsediment are listed in table 11. Concentrations of miscellaneous organic compounds identified in the elutriates are given in table 12.

Bottom-sediment elutriates from JC-01 contained detectable concentrations of three VOC's, two semi-volatile organic compounds, and three 
Table 9. Volatile and semi-volatile water-extractable organic compounds for which sediment elutriates were analyzed

[Analyses by U.S. Environmental Protection Agency]

Volatile organic compounds

Acetone
Benzene
Bromobenzene
Bromochloromethane
Bromodichloromethane
Bromoform
Bromomethane
Carbon disulfide
Carbon tetrachloride
Chlorobenzene
Chloroethane
Chloroform
Chloromethane
O-Chlorotoluene
P-Chlorotoluene
Dibromochloromethane
Dibromomethane

1,2-Dichlorobenzene

1,3-Dichlorobenzene

1,4-Dichlorobenzene

1,1-Dichloroethane

1,2-Dichloroethane

1,1-Dichloroethene

cis-1,2-Dichloroethene

trans-1,2-Dichloroethene

1,2-Dichloropropane

1,3-Dichloropropane

2,2-Dichloropropane

1,1-Dichloropropene

cis-1,3-Dichloropropene

trans-1,3-Dichloropropene

Dimethyl disulfide

Ethylbenzene

Methyl butyl ketone
Methyl ethyl ketone

Methyl isobutyl ketone

Methylene chloride

Styrene

1,1,1,2-Tetrachloroethane

1,1,2,2-Tetrachloroethane

Tetrachloroethene

Toluene

1,1,1-Trichloroethane

1,1,2-Trichloroethane

Trichloroethene

Trichlorofluoromethane

1,2,3-Trichloropropane

Vinyl acetate

Vinyl chloride

(M- and/or P-)Xylene

O-Xylene

Semi-volatile water-extractable organic compounds

\author{
Acenaphthene \\ Acenaphthylene \\ Anthracene \\ Benzo (a) anthracene \\ Benzo (b and/or k) fluoranthene \\ Benzo $(g, h, i)$ perylene \\ Benzo (a) pyrene \\ Benzoic acid \\ Benzyl alcohol \\ 4-Bromophenylphenylether \\ Butylbenzylphthalate \\ 4-Chloroaniline \\ bis (2-Chloroethoxy) methane \\ bis (2-Chloroethyl) ether \\ bis (2-Chloroisopropyl) ether \\ 4-Chloro-3-methylphenol \\ 2-Chloronaphthalene \\ 2-Chlorophenol \\ 4-Chlorophenylphenylether \\ Chrysene \\ Dibenzo $(\mathrm{a}, \mathrm{h})$ anthracene
}

Dibenzofuran

3,3'-Dichlorobenzidine

2,4-Dichlorophenol

Diethylphthalate

2,4-Dimethylphenol

Dimethylphthalate

Di-n-butylphthalate

4,6-Dinitro-2-methylphenol

2,4-Dinitrophenol

2,4-Dinitrotoluene

2,6-Dinitrotoluene

Di-n-octylphthalate

bis (2-Ethylhexyl) phthalate

Fluoranthene

Fluorene

Hexachlorobenzene

Hexachlorobutadiene

Hexachlorocyclopentadiene

Hexachloroethane

Indeno $(1,2,3-c, d)$ pyrene

Isophorone
2-Methylnaphthalene

2-Methylphenol

3- and/or 4-Methylphenol

Naphthalene

2-Nitroaniline

3-Nitroaniline

4-Nitroaniline

Nitrobenzene

2-Nitrophenol

4-Nitrophenol

n-Nitroso-di-n-propylamine

n-Nitrosodiphenylaminel

diphenylamine

Pentachlorophenol

Phenanthrene

Phenol

Pyrene

2,3,4,6-Tetrachlorophenol

1,2,4-Trichlorobenzene

2,4,5-Trichlorophenol

2,4,6-Trichlorophenol 


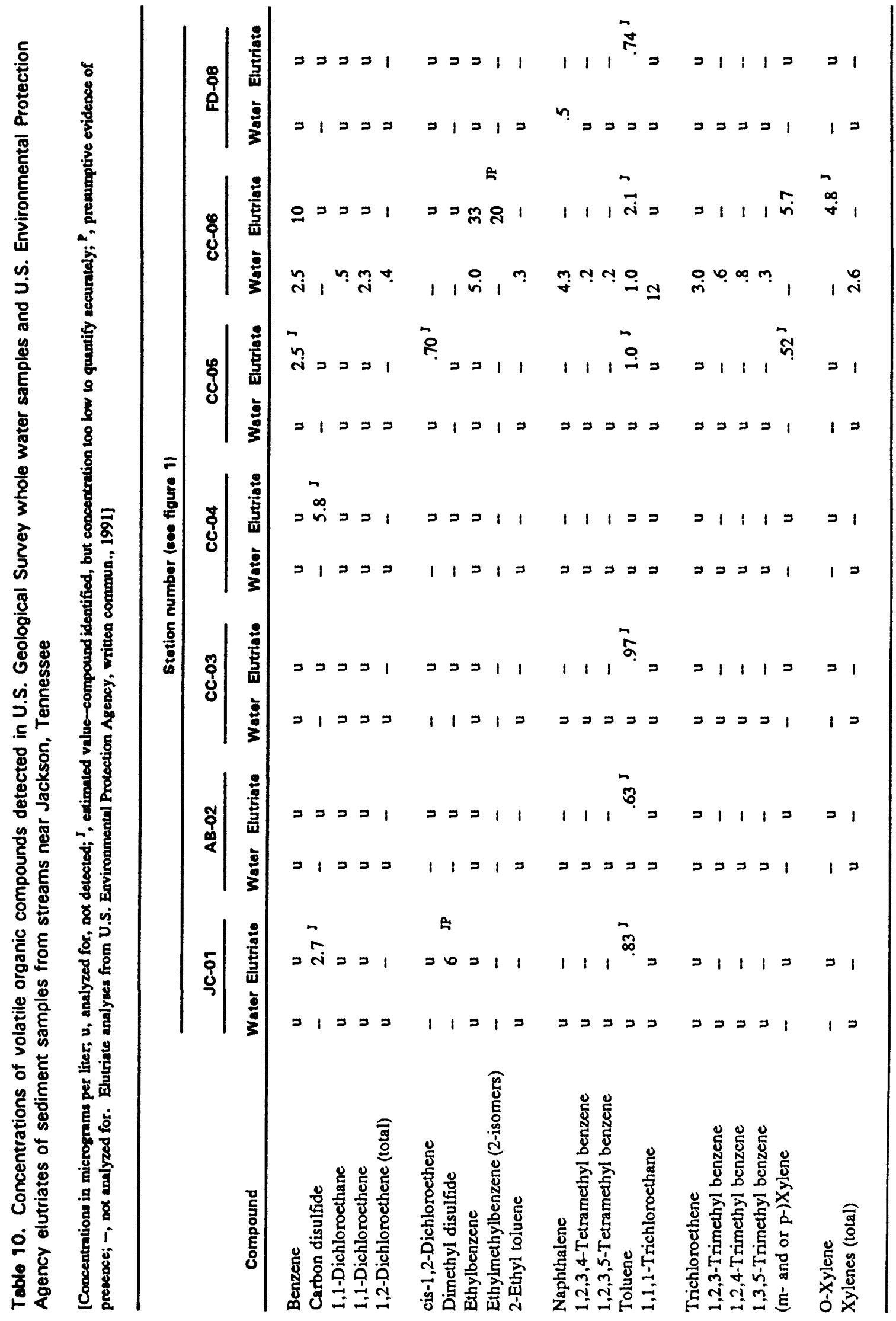




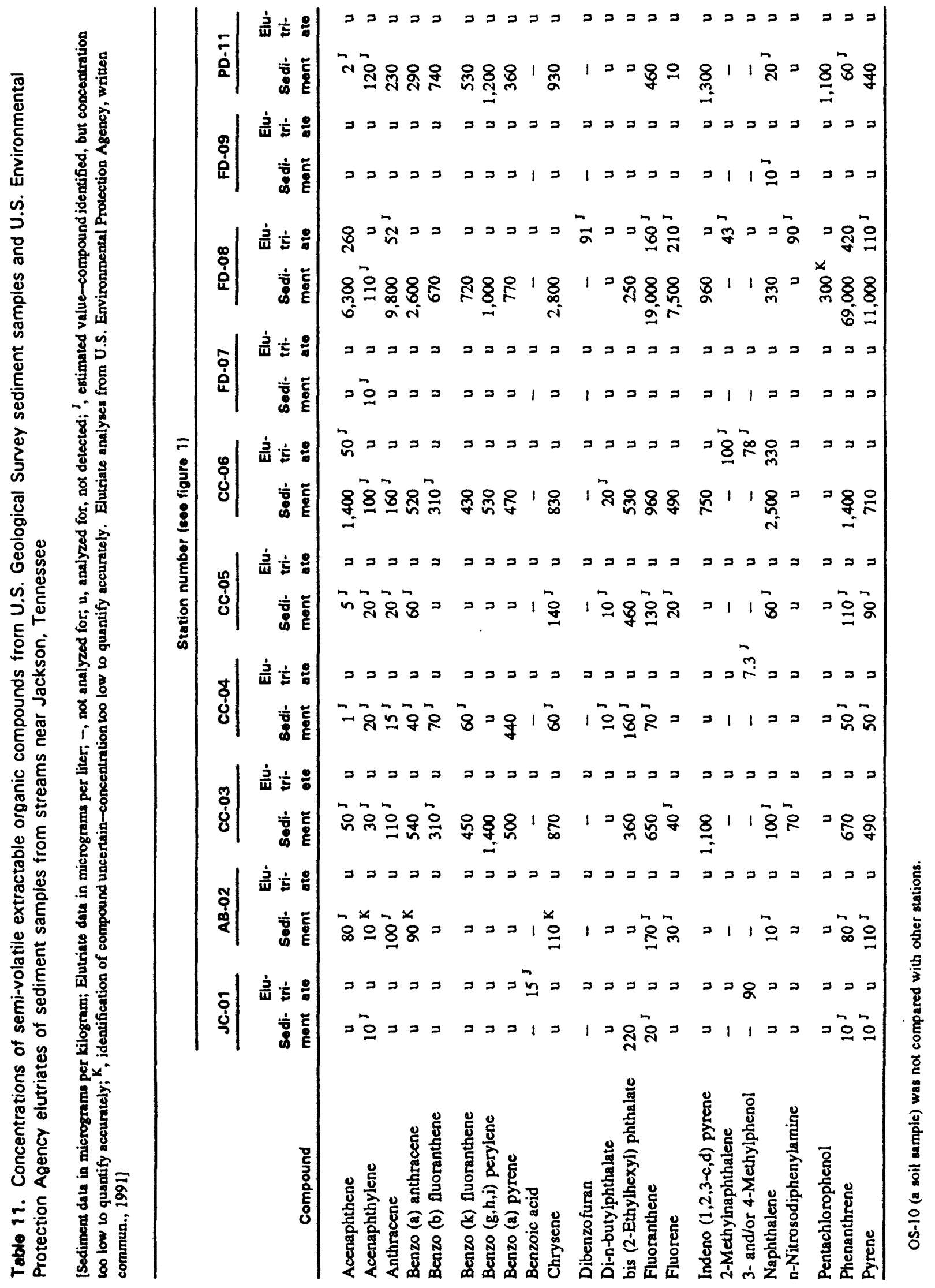

18 Water Quality, Organic Chemistry of Sediment, and Biological Conditione of Streams

Near an Abandoned Wood-Preserving Plant site at Jackson, Tennessee 
Table 12. Miscellaneous extractable organic compounds detected in elutriates of sediment samples from streams near Jackson, Tennessee

[Concentration in micrograms per liter; $x$, compound not identified; J, estimated value-compound identified, but concentration too low to quantify accurately; ${ }^{\text {, }}$, presumptive evidence of presence. Elutriate anslyses from U.S. Environmental Protection Agency, written commun., 1991]

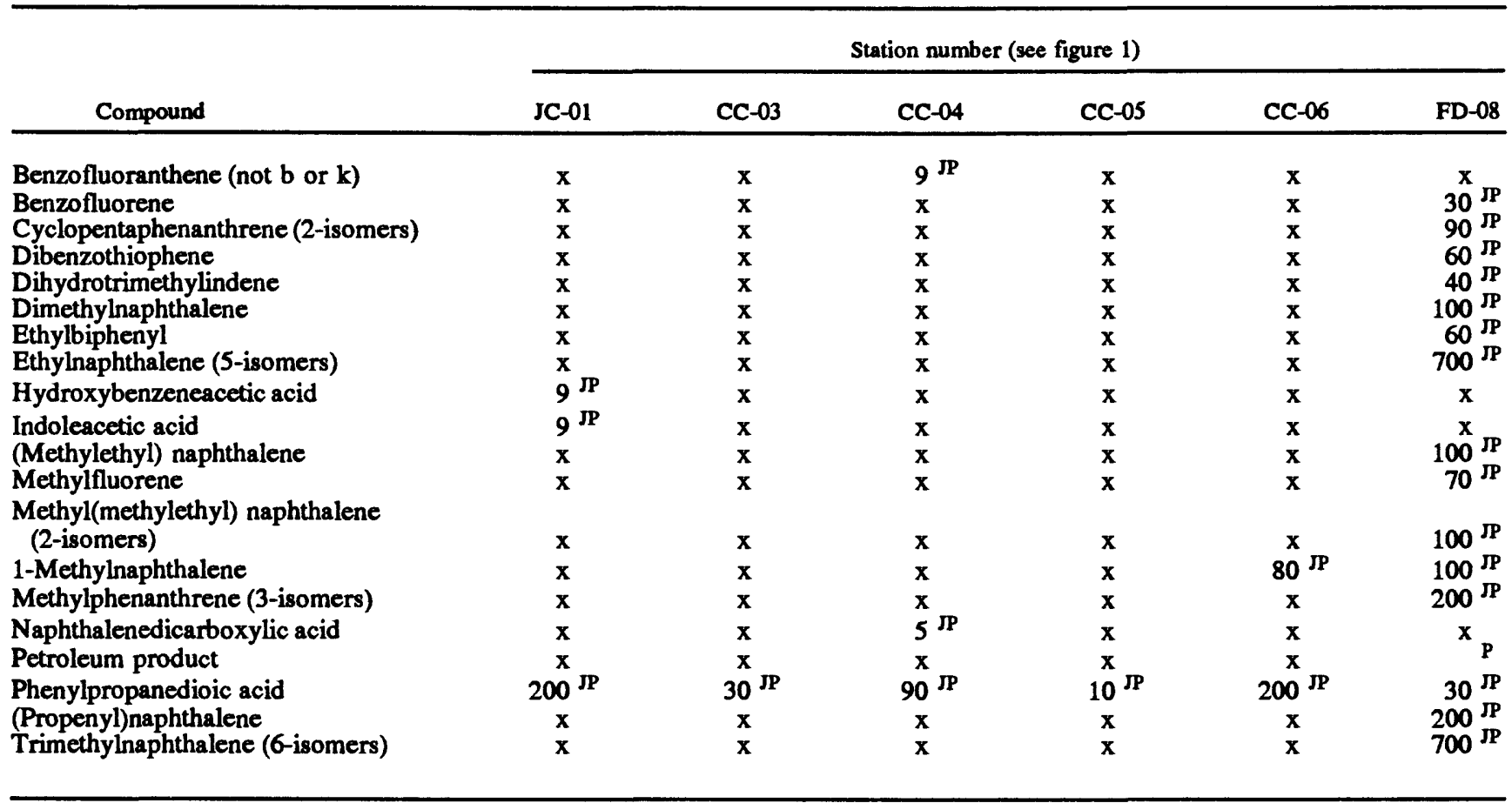

miscellaneous organic acids. The elutriate from AB-02 sediment contained one VOC. Concentrations of organic compounds in the elutriate samples were too low to accurately quantify, except that of 3- and or 4-methylphenol $(90 \mu \mathrm{g} / \mathrm{L})$ in the elutriate of sediment from JC- 01 .

The elutriates of bottom sediment from stations CC-03, CC-04, and CC-05 contained one to four VOC's, one semi-volatile organic compound, and one to three miscellaneous organic compounds. Concentrations of each compound were too low to quantify accurately. Toluene, a VOC, was identified in the elutriates of sediment from two stations, and phenylpropanedioic acid, a miscellaneous organic compound, was identified in the elutriates of sediment from all three stations. In comparison, 12 to 17 semi-volatile organic compounds were identified in the bottom sediment from each of these stations using the methylene-chloride extraction procedure (table 8).
The number of organic compounds identified and concentrations of each in the bottom-sediment elutriate of $\mathrm{CC}-06$ were higher than in samples from stations upstream on Central Creek. The elutriate of this sample contained six VOC's, four semi-volatile organic compounds, and two miscellaneous organic compounds. The volatile constituents included benzene, ethylbenzene, and ( $\mathrm{m}$ - and or $\mathrm{p}$-) xylene in measurable concentrations. Concentrations of benzene and these isomers of xylene were about 4 and 10 times higher, respectively, at CC-06 than the estimated concentrations at CC-05. The semi-volatile constituents were acenapthene, 2-methylnaphthalene, 3- and or 4-methylphenol, and naphthalene, and are creosote related. The naphthalene concentration was $330 \mu \mathrm{g} / \mathrm{L}$; concentrations of the other three constitutents were high relative to other stations on Central Creek but too low to quantify accurately. Acenaphthene $(1,400 \mu \mathrm{g} / \mathrm{kg})$ and naphthalene $(2,500 \mu \mathrm{g} / \mathrm{kg})$ were 
detected in the bottom sediment from CC-06 using the methylene-chloride extraction procedure; analyses were not made by this procedure for the other two compounds detected in the elutriate. Two miscellaneous organic compounds were detected in the water-extracted elutriate for this station, but concentrations were too low to accurately quantify.

The water-extracted bottom-sediment elutriate of FD-08 on the South Fork Forked Deer River contained the greatest number of organic compounds detected in the elutriate of any of the stations sampled. Station FD-08 elutriate contained 1 VOC, 9 semi-volatile organic compounds, and 16 miscellaneous organic compounds. Concentrations of acenapthene $(260 \mu \mathrm{g} / \mathrm{L})$ and phenanthrene $(420 \mu \mathrm{g} / \mathrm{L})$ were sufficient to quantify; concentrations of all of the other compounds were estimates. No organic compounds were detected in the water-extracted elutriates of FD-07 or FD-09 on the South Fork Forked Deer, or of PD-11.

Elevated concentrations of creosote-related compounds in water and bottom-sediment samples from stations CC-06 and FD-08, near the confluence of Central Creek with the South Fork Forked Deer River, indicate that this part of the study area has been most affected by compounds discharged from the wood-preserving plant site. It is apparent from tables 5 and 6 that the water of Central Creek at station CC-06 has been degraded more substantially by organic compounds than the water at any other station sampled. Concentrations of compounds detected in Central Creek appear to have been diluted in the South Fork Forked Deer to the extent that only two were detectable at station FD-08. However, from tables 8, 10,11, and 12, it is also apparent that bottom material at station FD-08 has been more contaminated by organic compounds than at any other stream station. Sediment from station FD-08 had the largest number of organic compounds and, in most comparisons, the highest concentrations of those compounds.

\section{BIOLOGICAL CONDITIONS}

Water and bottom-sediment samples were collected from the nine stream stations and the drainage ditch to assess the toxicity of the water and sediment to selected organisms. In addition, one soil sample was collected from OS-10 to determine the toxicity of soils known to contain organic compounds from the wood-preserving plant. All samples were collected and analyzed according to procedures described in "Standard Operating Procedures for Toxicity Testing, Hazardous Waste Assessment" (ManTech Environmental Technology, Inc., 1990). Chain-of-custody was maintained during field and laboratory activities.

Floral and faunal surveys were conducted at stations on Central Creek, the two streams unaffected by the plant, and the South Fork Forked Deer River. Biological samples were collected to determine the species composition and population density of organisms comprising the algal, benthic invertebrate, and fish communities.

\section{Toxicity}

Short-term chronic toxicity tests using water samples, elutriates of bottom sediment, and soil samples were conducted. The purpose of the tests was to determine if survival, growth, and reproduction rates of organisms were significantly affected by undiluted (100 percent) samples compared to laboratory control samples. The test organisms used were Ceriodaphnia dubia (a freshwater crustacean), Pimephales promelas (fathead minnow), Lactuca sativa (rooted macrophyte), Photobacterium phosphoreum (bacterium), and Selenastrum capricornutum (green algae). In addition, Lactuca sativa and Lumbriculus variegatus (sediment worm) were subjected to singleconcentration chronic tests, and Eisenia andrei (earthworm) was subjected to a multi-concentration chronic test, using whole bottom-sediment and soil samples.

Survival rates of Ceriodaphnia dubia were not affected by any water sample (table 13). Although the number of young produced in samples from $\mathrm{AB}-02$ and $\mathrm{CC}-05$ was less than that in the laboratory control samples, the reproduction of $C$. dubia averaged over 15 young per female, indicating little if any toxicity (A.G. Auwarter, U.S. Environmental Protection Agency, written commun., 1991). 


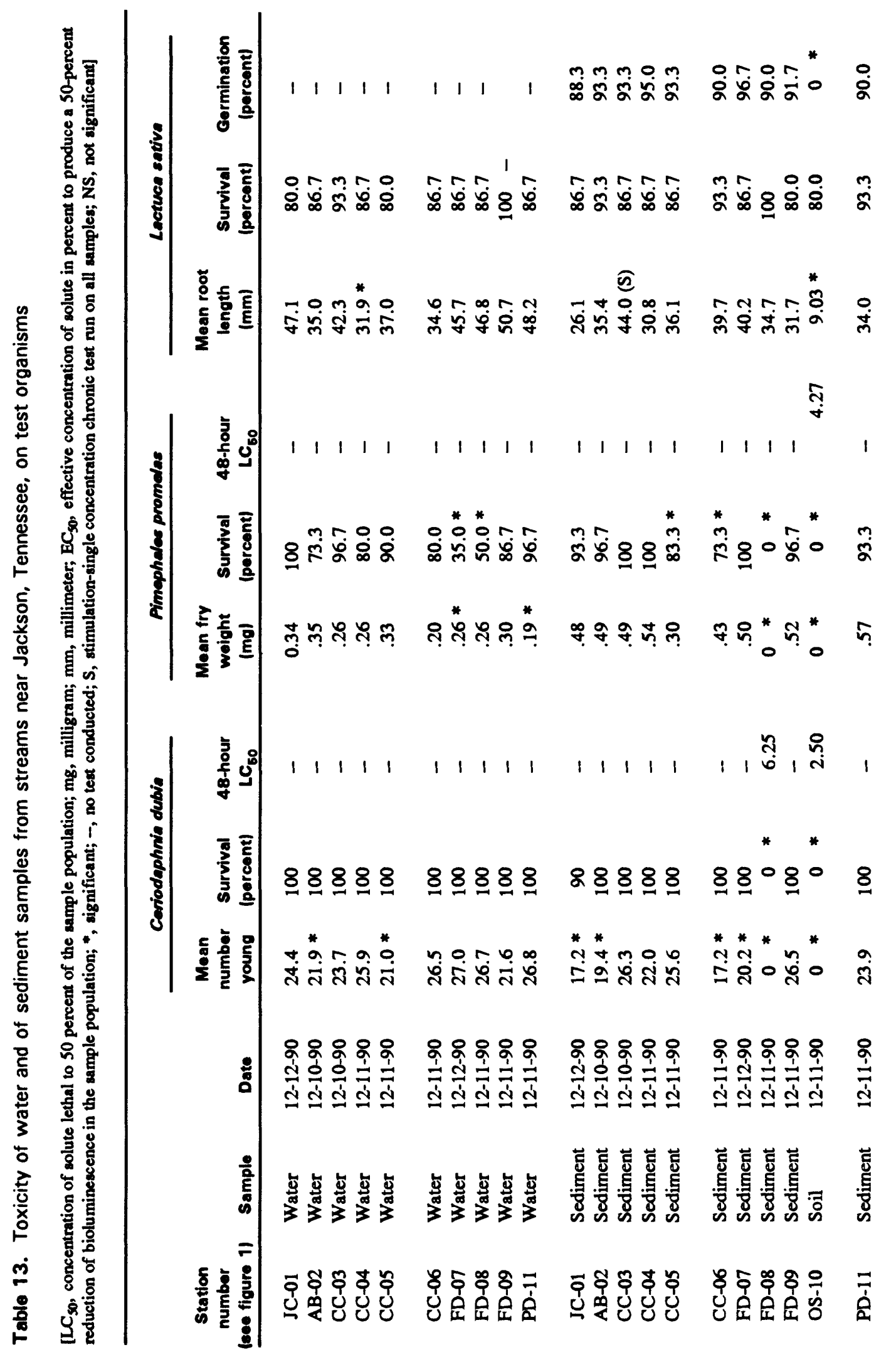




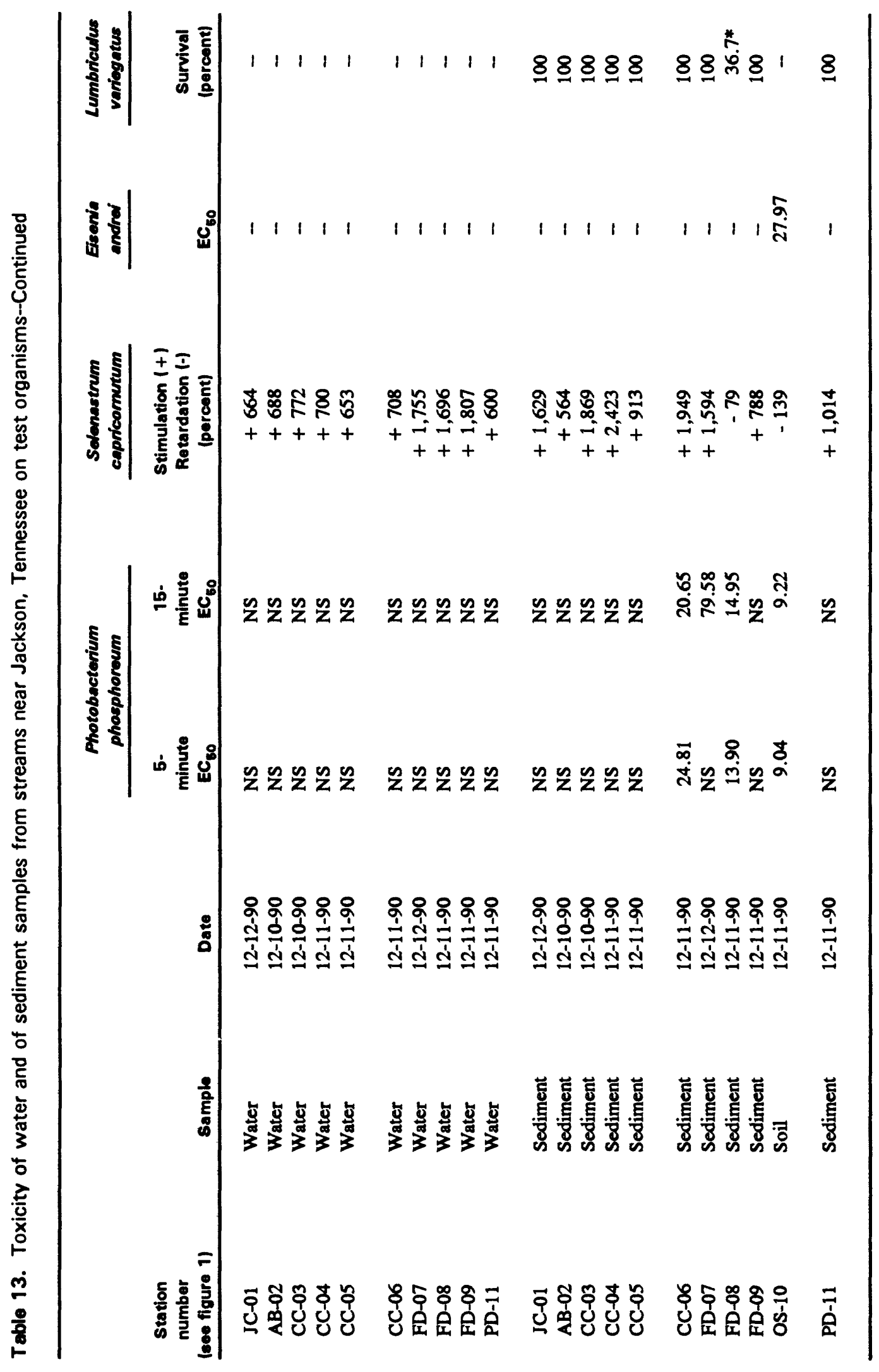


The bottom-sediment elutriate from FD-08 and the soil elutriate from OS-10 were acutely toxic to C. dubia; these samples caused death to all individuals. The 48-hour $\mathrm{LC}_{50}$ 's (concentration of solute lethal to 50 percent of the sample population) were 6.25 percent of the sample concentration for station FD-08 and 2.50 percent for station OS-10. The bottom-sediment sample for this test was collected from a depositional area and had a definite creosote odor (A.G. Auwarter, written commun., 1991). Slight chronic toxicity (reduction in the mean number of young produced) was determined in tests using bottom-sediment elutriate samples from JC-01, AB-02, CC-06, and FD-07. The mean number of young in these samples was substantially less than those of the laboratory control samples, suggesting some toxicity. However, the number of young was greater than the minimum of 15 expected in the control samples (table 13). The toxicity to $C$. dubia in samples from JC-01 and AB-02 suggests possible contamination from unknown sources.

Toxicity tests using water from Central Creek, Jones Creek, and Anderson Branch indicated no significant effects to survival of Pimephales promelas (fathead minnows) (table 13). Two water samples from the South Fork Forked Deer River (FD-07, FD-08) did have a significant effect on survival rates. Water from FD-07 resulted in only a 35-percent survival rate, but because this sampling station is located upstream from Central Creek, the likely cause of mortality was contamination from sources other than the wood-preserving plant site. Survival in water samples from FD-08 also was significantly affected, with only a 50-percent survival rate of individuals. Because no significant toxicity to $P$. promelas was detected in the Central Creek samples, surface water entering the South Fork at the confluence of Central Creek is assumed not to be the primary carrier of the toxic material.

Slight chronic effects in growth rates were indicated by the mean fry weight of $P$. promelas in toxicity tests using samples from sites FD-07 and PD-11. However, USEPA investigators concluded that these effects were due to variations in growth of the individuals and were within the range measured in other samples (A.G. Auwarter, written commun., 1991).

Bottom-sediment elutriate samples from $\mathrm{CC}-05$ and CC-06 caused significant adverse effects on survival of individual minnows. Survival rates were 83.3 percent at $\mathrm{CC}-05$ and 73.3 percent at CC-06. The bottom-sediment elutriate sample from FD-08 was acutely toxic to all fathead minnows. The sample caused death to all individuals exposed to it during the chronic test, but because all minnows survived longer than 48 hours before dying, a 48-hour $\mathrm{LC}_{50}$ determination could not be made. The soil elutriate from OS-10 also was toxic to all fathead minnows. The 48-hour $\mathrm{LC}_{50}$ of this elutriate for $P$. promelas was 4.27 percent. The growth of surviving fry did not appear to be affected by any of the bottom-sediment elutriates tested.

Lactuca sativa exhibited chronic effect in mean root length elongation when exposed to a water sample from CC-04 (table 13). Mean root lengths from seeds exposed to water from $\mathrm{CC}-04$ were 31.9 millimeters (1.26 inches), significantly less than those of the laboratory control samples. No acute toxicity to seeds exposed to the water samples was noted. In addition, tests using bottom-sediment elutriates and whole bottom sediments from all sampling stations did not indicate any significant toxic effects on germination and survival rates, or root development. Tests using the soil elutriate from OS-10 resulted in a significant reduction in mean root length. Zero-percent germination of $L$. sativa occurred in the soil sample from OS-10.

Photobacterium phosphoreum cultures did not exhibit any toxic response to water samples from any of the stations (table 13). However, for the 5and 15-minute $\mathrm{EC}_{50}$ 's (effective concentration of solute to produce a 50 -percent reduction of bioluminescence in sample population), bottom-sediment and soil elutriate samples from CC-06 and FD-08 were highly toxic to these bacteria. Sediment elutriates from FD-07, upstream of inflow from the plant site area, also indicated some toxicity, with a 15-minute $\mathrm{EC}_{50}$ of 79.58 percent.

Selenastrum capricornutum did not show chronic toxicity to water samples from any of the stations (table 13). Algal growth was stimulated from 600 to 1,807 percent, indicating that the 
waters were nutrient rich (A.G. Auwarter, written commun., 1991). The bottom-sediment elutriate from FD-08 was toxic to algae cultures. Algal growth in elutriate from FD-08 was inhibited by 79 percent, whereas all other bottom-sediment elutriates stimulated algal growth by 564 to 2,423 percent. The soil elutriate from OS-10 also was toxic to $S$. capricornutum. The algae culture for this station was inhibited by 139 percent.

All whole bottom sediments were tested for toxicity using a sediment worm, Lumbriculus variegatus. Only one sample, FD-08, caused significant toxicity to these organisms, resulting in a 36.7-percent survival rate (table 13). This sample was noted by USEPA investigators as having a creosote odor (A.G. Auwarter, written commun., 1991). The soil sample from OS-10 was not tested for toxicity to $L$. variegatus.

As noted in preceding discussion, the single soil sample collected at OS-10 was toxic to all organisms tested. Tests of elutriates indicated a 48-hour $\mathrm{LC}_{50}$ to $P$. promelas of 4.27 percent. $L$. sativa exhibited a decrease in root length by 75 percent, whereas germination in the whole soil was reduced to 0 percent. Results of $\mathrm{EC}_{50} 5$ - and 15-minute tests on $P$. phosphoreum subjected to soil elutriates were 9.04 and 9.22 percent, respectively. Algal growth ( $S$. capricornutum) was retarded by 139 percent. The whole soil sample from OS-10 also was tested to determine any behavioral effects on the earthworm Eisenia andrei. The $\mathrm{EC}_{50}$ of the soil sample on $E$. andrei was 27.97 percent (table 13).

In their evaluation of the results of the various toxicity tests, the USEPA investigators concluded that the soils of the wood-preserving plant site are still (1990) highly toxic (A.G. Auwarter, written commun., 1991). The soil sample collected on-site at OS-10 and the streambed sediment collected at FD-08 indicated that significant toxicity remains onsite, and that toxic matter is buried in the bottom sediment of the river near FD-08. It is not known whether the toxic matter at FD-08 is from the deposition of contaminated sediment from the plant site in local pockets that have been covered by successive layers of stream sediment, or if it may be from the sorption by bottom material of contami- nants that have entered the river in ground-water discharge.

The adverse effects of creosote-related compounds on the aquatic communities inhabiting the South Fork Forked Deer River near station FD-08 might be mitigated by the river's large discharge and suspended-sediment load. Even after these ameliorating factors are considered, however, the potential for adverse affects to the biota still appears substantial due to the high concentrations of organic contaminants present in the bottom sediment.

\section{Biotic Communities}

The composition and relative abundance of species comprising algal communities were determined from samples collected by scraping rocks and wood debris from available habitat, or from sediment. Benthic invertebrates were collected using the "kick" sample method in which substrate was disturbed for a fixed time interval, during which time any organisms dislodged were collected in a net having mesh openings of 210 microns. Fish for use in tissue analysis were collected using a backpack electro-shocking unit.

Periphyton (algae) communities contained from 11 to 39 species. Blue-green algae dominated the samples from Central Creek (about 43-79 percent) and the South Fork Forked Deer River (45-70 percent) (table 14). Samples from Jones Creek and Anderson Branch contained about 57 percent diatoms, generally considered to be more sensitive to pollution than blue-green algae. The abundance of diatoms was lowest in Central Creek. The lowest percentage of diatoms (11 percent) and the highest percentage of blue-green algae (79 percent) occurred at the most downstream site on Central Creek, possibly because of the degraded waterquality conditions. The predominant taxa at Central Creek sites were species of Oscillatoria, Synechococcus, Phormidium, and Chlorella. Algae identified at each station are listed in Appendix 1.

The benthic invertebrate communities at all stations contained few species and few individuals because of degraded water-quality conditions and 
Table 14. Relative abundance of periphyton species identified at surface-water sampling stations near Jackson, Tennessee

[All units are percent of total sample]

\begin{tabular}{lcccc}
\hline & \multicolumn{3}{c}{ Classes identified } \\
\cline { 2 - 5 } $\begin{array}{c}\text { Station } \\
\text { number } \\
\text { (soe figure 1) }\end{array}$ & Diatoms & Green algae & Blue-green algae & Cryptophyta \\
\hline JC-01 & 57.1 & 14.8 & 28.1 & 0 \\
AB-02 & 56.8 & .7 & 42.5 & 0 \\
CC-03 & 28.4 & 11.9 & 59.7 & 0 \\
CC-04 & 37.1 & 12.1 & 50.8 & 0 \\
CC-05 & 44.4 & 12.1 & 43.5 & 0 \\
& & & & .3 \\
CC-06 & 11.2 & 10.0 & 78.5 & 1.9 \\
FD-07 & 14.7 & 13.1 & 70.3 & 1.5 \\
FD-08 & 44.5 & 8.5 & 45.5 & 0 \\
FD-09 & 25.5 & 13.9 & 60.6 & \\
\hline
\end{tabular}

unfavorable habitat. The number of taxa ranged from four to six species in Central Creek (table 15). Most organisms were Nais species (worms), or Physa species (snails), indicating relatively poor water-quality. The number of individuals in samples from Central Creek ranged from 16 at $\mathrm{CC}-06$ to 152 at $\mathrm{CC}-03$. Of the 152 organisms at CC-03, 141 were worms, indicating low community diversity and degraded conditions. An inventory of fish and benthos collected at each station is given in Appendix 2.

A larger number of "clean water" organisms such as Ephemeroptera (mayflies) and Plecoptera (stoneflies) were found in the South Fork Forked Deer River relative to that found in Central Creek. The number of taxa (4-10) and the number of individual organisms (36-62) in the South Fork Forked Deer were low, probably because of unfavorable habitat rather than degraded water quality. Most organisms were collected from leaf packs in the river.

Fish communities also were rather sparse, containing low numbers of tolerant species. Samples from Central Creek contained 3 to 5 species and 12 to 38 individual organisms, most of which were Gambusia affinis (mosquitofish) and Lepomas cyanellus (green sunfish) (table 15 and Appendix 2). Samples from stations FD-07 and FD-08 on the South Fork Forked Deer River contained similar numbers of species with the number of individuals ranging from 11 to 17 . Water at FD-09 on the South Fork Forked Deer was too deep for electro-shocking and no fish were collected.

The fish sample from Jones Creek contained 10 species of fish and 81 individuals, indicating better water quality or more favorable habitat. The community was dominated by Notropis boops (bigeye shiner) and contained three species of Etheostoma (darters). Darters are generally considered to be more sensitive to pollution than the more tolerant taxa collected from Central Creek. Fish from Anderson Branch were not as diverse nor as numerous as those in Jones Creek (Appendix 2).

\section{Fish-Tissue Analyses}

Whole fish samples from eight stream stations were analyzed for 68 organic compounds (table 16). No fish were collected from FD-09, the most downstream station on the South Fork Forked Deer River, although fish most likely were present in this reach of the river. Samples were composites of several small fish in order to have enough tissue for analyses by USEPA Method 8270 (U.S. Environmental Protection Agency, 1986). 
Table 15. Diversity of fish and benthic species identified at surface-water sampling stations near Jackson, Tennessee

$[-$, no samples collected $]$

\begin{tabular}{cccccc}
\hline \multirow{2}{*}{$\begin{array}{c}\text { Station } \\
\text { number } \\
\text { (see figure 1) }\end{array}$} & \multicolumn{2}{c}{ Fish } & \multicolumn{3}{c}{ Benthos } \\
\cline { 2 - 3 } \cline { 5 - 6 } \cline { 5 - 5 } JC-01 & Number of species & Number of individuals & & Number of species & Number of individuals \\
AB-02 & 10 & 81 & 8 & 40 \\
CC-03 & 6 & 13 & 3 & 14 \\
CC-04 & 3 & 38 & 4 & 28 \\
CC-05 & 5 & 12 & 6 & 131 \\
CC-06 & 4 & 14 & 6 & 16 \\
FD-07 & 3 & 13 & 4 & 36 \\
FD-08 & 5 & 17 & 10 & 62 \\
1 FD-09 & 4 & 11 & 8 & 51 \\
\hline
\end{tabular}

${ }^{1}$ Channel too deep for effective seining or electro-shocking.

Table 16. Semi-volatile organic compounds for which fish tissue was analyzed

\author{
Acenaphthene \\ Acenaphthylene \\ Aniline \\ Anthracene \\ Benzo (a) anthracene \\ Benzo (b) fluoranthene \\ Benzo (k) fluoranthene \\ Benzo $(g, h, i)$ perylene \\ Benzo (a) pyrene \\ Benzoic acid \\ Benzyl alcohol \\ 4-Bromophenylphenylether \\ Butylbenzylphthalate \\ 4-Chloro-3-methylphenol \\ 4-Chloroaniline \\ bis (2-Chloroethoxy) methane \\ bis (2-Chloroethyl) ether \\ bis (2-Chloroisopropyl) ether \\ 2-Chloronaphthalene \\ 2-Chlorophenol \\ 4-Chlorophenylphenylether \\ Chrysene \\ Dibenzo $(\mathrm{a}, \mathrm{h})$ anthracene
}

Dibenzofuran

1,2-Dichlorobenzene

1,3-Dichlorobenzene

1,4-Dichlorobenzene

3,3'-Dichlorobenzidine

2,4-Dichlorophenol

Diethylphthalate

2,4-Dimethylphenol

Dimethylphthalate

Di-n-butylphthalate

4,6-Dinitro-2-methylphenol

2,4-Dinitrophenol

2,4-Dinitrotoluene

2,6-Dinitrotoluene

Di-n-octylphthalate

bis (2-Ethylhexyl) phthalate

Fluoranthene

Fluorene

Hexachlorobenzene

Hexachlorobutadiene

Hexachlorocyclopentadiene

Hexachloroethane

Indeno $(1,2,3-c, d)$ pyrene
Isophorone

2-Methylnaphthalene

2-Methylphenol

4-Methylphenol

Naphthalene

2-Nitroaniline

3-Nitroaniline

4-Nitroaniline

Nitrobenzene

2-Nitrophenol

4-Nitrophenol

n-Nitrosodimethylamine

n-Nitroso-di-n-propylamine

n-Nitrosodiphenylamine

Pentachlorophenol

Phenanthrene

Phenol

Pyrene

Pyridine

1,2,4-Trichlorobenzene

2,4,5-Trichlorophenol

2,4,6-Trichlorophenol 
No organic compounds were detected in fish tissue from Jones Creek. Low concentrations, 0.62 to $2.2 \mu \mathrm{g} / \mathrm{kg}$, of di-n-butylphthalate were detected in fish-tissue samples from Anderson Branch, all Central Creek stations, and FD-08. This compound is not suspected of having originated from the wood-preserving plant site. Fish-tissue samples from FD-07, the upstream station on the South Fork Forked Deer, contained $0.57 \mu \mathrm{g} / \mathrm{kg}$ of benzyl alcohol (table 17). The source of this compound is unknown.

Low concentrations of 4-methylphenol were detected in fish-tissue samples collected from the upstream station (CC-03) and one of the stations adjacent to the plant site (CC-05) on Central Creek. Concentrations of 4-methylphenol in fish-tissue sample composites were $2.3 \mu \mathrm{g} / \mathrm{kg}$ and $2.2 \mu \mathrm{g} / \mathrm{kg}$ for stations $\mathrm{CC}-03$ and $\mathrm{CC}-05$, respectively (table 17). Because the compound was not detected in tissue samples from downstream stations CC-06, FD-07, or FD-08, the presence of 4-methylphenol, a creosote constituent, at stations $\mathrm{CC}-03$ and $\mathrm{CC}-05$ might be the result of surface runoff from past facility activities, upstream sources, or fish migration.

Tissue samples from fish collected from CC-06 contained detectable concentrations of four organic compounds found in creosote (table 17). The compounds are naphthalene $(3.7 \mu \mathrm{g} / \mathrm{kg})$, dibenzofuran $(3.6 \mu \mathrm{g} / \mathrm{kg})$, fluorene $(3.9 \mu \mathrm{g} / \mathrm{kg})$, and phenanthrene $(1.5 \mu \mathrm{g} / \mathrm{kg})$. The presence of these compounds indicates drainage from the wood-preserving plant

Table 17. Organic compounds detected in tissue of fish near Jackson, Tennessee

[Whole fish samples; concentrations in micrograms per kilogram; ${ }^{*}$, organochlorine insecticide]

\begin{tabular}{clcc}
\hline $\begin{array}{c}\text { Station } \\
\text { number } \\
\text { (see figure 1) }\end{array}$ & Compound & Concentration & $\begin{array}{c}\text { Reporting } \\
\text { level }\end{array}$ \\
\hline AB-02 & Di-n-butylphthalate & 0.67 & 0.4 \\
CC-03 & Benzyl alcohol & .4 & .4 \\
& 4-Methylphenol & .4 \\
Di-n-butylphthalate & Benzyl alcohol & 2.3 & .4 \\
CC-04 & Di-n-butylphthalate & .62 & .4 \\
& Endosulfan I** & .42 & .4 \\
Dieldrin** & .67 & 2.0 \\
CC-05 & 4-Methylphenol & 2.8 & 4.1 \\
& Di-n-butylphthalate & 4.9 & 1.2 \\
CC-06 & Naphthalene & 2.2 & 1.2 \\
& Dibenzofuran & 1.8 & 1.0 \\
& Di-n-butylphthalate & 3.7 & 1.0 \\
& Fluorene & 3.6 & 1.0 \\
FD-07 & Phenanthrene & 1.7 & 1.0 \\
FD-08 & Benzyl alcohol & 3.9 & 1.0 \\
& Di-n-butylphthalate & 1.5 & .5 \\
\hline
\end{tabular}


site had adverse effects on fish in this reach of Central Creek. Fish-tissue data support other chemical data on water and bottom sediment that identify this station as being in the area most affected by discharge from the wood-preserving plant site.

\section{SUMMARY AND CONCLUSIONS}

Water-quality and biological data were collected in December 1990 from streams near an abandoned Superfund site, formerly used for impregnating wood with preservatives, at Jackson, Tennessee. The purpose of sampling was to assess the extent of contamination of nearby streams and biota by creosote-based compounds discharged from the wood-preserving plant site. Media sampled included water, bottom sediments, soil, and aquatic organisms from nine stations at or near the plant site and from two stations on unaffected streams near the city of Jackson.

Surface waters and bottom sediments near the plant site contained detectable levels of creosote constituents and pentachlorophenol, classified as priority pollutants by USEPA. These compounds are suspected of having been transported from the site to nearby streams by ground water and surface runoff. However, because many creosote constituents were detected in low concentrations in bottom-sediment samples from sampling stations upstream of the plant, other industrial and nonpoint sources of contamination probably have contributed to the chemical load.

The most pronounced degradation of surfacewater quality from the wood-preserving plant site has occurred along the lower reach of Central Creek, which bounds the site to the north and west. Between the upstream sampling station (CC-03) and the most downstream station ( $\mathrm{CC}-06)$, the dissolved-chloride concentration increased from 13 to $41 \mathrm{mg} / \mathrm{L}$, dissolved solids increased from 204 to $262 \mathrm{mg} / \mathrm{L}$, and specific conductance increased from 348 to $465 \mu \mathrm{S} / \mathrm{cm}$. At station CC-06, specific conductance values were three to nine times greater than the values measured in samples from other area streams. Nine VOC's were detected in the surface-water sample from CC-06, whereas only one was detected in the samples from other stations. Thirteen acid and base neutral extractable organic compounds were detected in the water sample from CC-06. The compounds include naphthalene, the single most abundant constituent of coal tar, in a concentration of $16 \mu \mathrm{g} / \mathrm{L}$, and pentachlorophenol, a wood preservative, in a concentration of $30 \mu \mathrm{g} / \mathrm{L}$. The pentachlorophenol concentration exceeded Tennessee's criterion maximum concentration of $9 \mu \mathrm{g} / \mathrm{L}$ for fish and aquatic life. For comparison, only two acid and base neutral extractable organic compounds were detected in surface water from each of two other stations, and concentrations in those samples were too small to measure accurately.

Of the four sampling stations on Central Creek, CC-06 had the highest concentrations of most methylene-chloride extractable organic compounds detected in bottom sediment. Creosote-related compounds in large concentrations include naphthalene $(2,500 \mu \mathrm{g} / \mathrm{kg})$, phenanthrene $(1,400 \mu \mathrm{g} / \mathrm{L})$, and acenapthene $(1,400 \mu \mathrm{g} / \mathrm{L})$. The water-extractable elutriate of sediment from this station contained low concentrations of six VOC's, four creosote-related semi-volatile organic compounds, and two miscellaneous organic compounds. In laboratory tests, the sediment elutriate sample from $\mathrm{CC}-06$ produced slight chronic toxicity to $C$. dubia, caused significant effects on survival of $P$. promelas, and produced highly toxic effects to $P$. phosphoreum.

Species composition and diversity of periphyton, benthos, and fish at stations on Central Creek indicated degraded environmental conditions. In periphyton samples, the diatom population at station CC-06 had the least relative abundance of all stations (11 percent of total organisms), whereas blue-green algae had the greatest relative abundance (79 percent). Diatoms are generally considered to be sensitive to pollution, whereas blue-green algae are more pollution tolerant. In benthic invertebrate samples from this station, only 4 species and 16 individuals were present. Most organisms were Nais species, indicating relatively poor water quality. The fish survey of $\mathrm{CC}-06$ yielded only 3 species and 13 individuals, most of which were Gambusia affinis and Lepomas cyanellus, considered to be pollution tolerant. Fish-tissue samples 
from CC-06 contained five organic compounds, the largest number of compounds observed among the stations sampled for fish. Four of the compounds detected are found in creosote.

Station FD-08 on the South Fork Forked Deer River, just below the confluence with Central Creek, had the greatest concentrations of methylene-chloride extractable organic compounds in bottom sediment of all stations sampled. One contributing factor for the relatively high contaminant load may be that station FD-08 had the highest percentage of organic matter in sediment, providing greater potential for the adsorption of organic compounds.

Analyses of water samples from this station indicated that only minor concentrations of one VOC and two semi-volatile organic compounds were detectable in the surface water. Seventeen methylene-chloride extractable organic compounds were identifiable in the bottom-sediment. The concentrations of eight compounds greatly exceeded the concentrations of corresponding compounds at other stations, excluding the drainage site. Compounds detected included acenaphthene $(6,300 \mu \mathrm{g} / \mathrm{kg})$, anthracene $(9,800 \mu \mathrm{g} / \mathrm{kg})$, chrysene $(2,800 \mu \mathrm{g} / \mathrm{kg})$, fluoranthene $(19,000 \mu \mathrm{g} / \mathrm{kg})$, fluorene $(7,500 \mu \mathrm{g} / \mathrm{kg})$, phenanthrene $(69,000 \mu \mathrm{g} / \mathrm{kg})$, pyrene $(11,000 \mu \mathrm{g} / \mathrm{kg})$, and benzo (a) anthracene $(2,600 \mu \mathrm{g} / \mathrm{kg})$. Low concentrations of 1 VOC, 9 semi-volatile organic compounds, and 16 miscellaneous organic compounds were detectable in the water-extractable sediment elutriate. In laboratory tests, sediment elutriate of this station was acutely toxic to $C$. dubia and $P$. promelas, highly toxic to $P$. phosphoreum, and significantly toxic to $S$. capricornutum. FD-08 was the only station where the whole sediment sample caused significant toxicity to $L$. variegatus.

Toxicity in the FD-08 area may result from the deposition of toxic sediment transported by Central Creek, and in surface runoff from the facility. It also may result from the sorption by sediment in the river of organic contaminants transported in the ground or surface waters discharged to the river.

Analysis of the on-site soil sample and the FD-08 sediment sample indicates that significant toxicity remains on-site and in the bottom sediment of the South Fork Forked Deer River near the con- fluence with Central Creek. The adverse effects of creosote-related compounds on the aquatic communities inhabiting the South Fork Forked Deer River near station FD-08 might be mitigated by the river's large discharge and suspended-sediment load. Even after these ameliorating factors are considered, however, the potential for adverse affects to the biota still appears substantial due to the high concentrations of organic contaminants present in the bottom sediment.

\section{SELECTED REFERENCES}

Britton, L.J., and Greeson, P.E., eds., 1989, Methods for collection and analysis of aquatic biological and microbiological samples: Techniques of WaterResources Investigations of the United States Geological Survey, Book 5, Chapter A4, 363 p.

Elder, J.F., and Dresler, P.V., 1986, Creosote discharge to the nearshore estuarine environment in Pensacola Bay, Florida: preliminary assessment of effects, in Movement and fate of creosote waste in ground water, Pensacola, Florida: U.S. Geological Survey Water-Supply Paper 2285, p. 59-63.

Fenneman, N.M., 1938, Physiography of eastern United States: New York, McGraw-Hill Inc., 714 p.

Friedman, L.C., and Erdmann, D.E., 1982, Quality assurance practices for the chemical and biological analyses of water and fluvial sediments: Techniques of Water-Resources Investigations of the United States Geological Survey, Book 5, Chapter A6, 181 p.

Godsy, E.M., and Goerlitz, D.F., 1986, Anaerobic microbial transformations of phenolic and other selected compounds in contaminated ground water at a creosote works, Pensacola, Florida, in Movement and fate of creosote waste in ground water, Pensacola, Florida: U.S. Geological Survey Water-Supply Paper 2285, p. 55-58.

Goerlitz, D.F., Godsy, E.M., Troutman, D.E., and Franks, B.J., 1986, Chemistry of ground water at a creosote works, Pensacola, Florida, in Movement and fate of creosote waste in ground water, Pensacola, Florida: U.S. Geological Survey Water-Supply Paper 2285, p. 49-53.

Guy, H.P., and Norman, V.W., 1970, Field methods of measurement of fluvial sediment: Techniques of Water-Resources Investigations of the United 
States Geological Survey, Book 3, Chapter C2, $59 \mathrm{p}$.

ManTech Environmental Technology Inc., 1990, Region

IV, Ecological Support Branch, Standard operating procedures for toxicity testing hazardous waste assessment; SOP XXII. Prepared by ManTech Environmental Technology, Inc., Environmental Services Assistance Team, Athens, Georgia, for the U.S. Environmental Protection Agency, Region IV, Environmental Services Division, Athens, Georgia (under contract no. 68-01-7456), March 1990.

Mattraw, H.C., and Franks, B.J., eds., 1986, Description of hazardous-waste research at a creosote works, Pensacola, Florida, in Movement and fate of creosote waste in ground water, Pensacola, Florida: U.S. Geological Survey Water-Supply Paper 2285, p. 1-17.

Merck and Co., Inc., 1983, The Merck Index--An encyclopedia of chemicals, drugs, and biologicals, 10th ed.: Rahway, New Jersey, 1,463 p. plus supplements.

Parks, W.S., and Carmichael, J.K., 1989, Geology and ground-water resources of the Fort Pillow Sand in western Tennessee: U.S. Geological Survey Water-Resources Investigations Report 89-4120, $20 \mathrm{p}$.

Plafkin, J.L., Barbour, M.T., Porter, K.D., Gross, S.K., and Hughes, R.M., 1989, Rapid bioassessment protocols for use in streams and rivers-benthic macroinvertebrates and fish: U.S. Environmental Protection Agency, EPA/444/4-89-001.
Skougstad, M.W., Fishman, M.J., Friedman, L.C., Erdmann, D.E., and Duncan, S.S., eds., 1979, Methods for determination of inorganic substances in water and fluvial sediments: Techniques of Water-Resources Investigations of the United States Geological Survey, Book 5, Chapter A1, $626 \mathrm{p}$.

Soil and Material Engineers, Inc., 1988, Final remedial investigation report (for) American Creosote Works Site, Jackson, Tennessee: Atlanta, Georgia, prepared for the U.S. Army Corps of Engineers, 2 vols.

Tennessee Department of Environment and Conservation, 1991, Chapter 1200-4-3, General water quality criteria, in Rules of Tennessee Department of Environment and Conservation, Bureau of Environment, Division of Water Pollution Control: p. 328-339.

U.S. Environmental Protection Agency, 1986, Test methods for evaluating solid wastes-physical/chemical methods: Washington, D.C., Office of Solid Waste and Emergency Response Report SW-846.

Weiss, G., ed., 1986, Hazardous chemicals data book (2d ed.): New Jersey, Noyes Data Corporation, $1,069 \mathrm{p}$.

Wershaw, R.L., Fishman, M.J., Grabbe, R.R., and Lowe, L.E. eds., 1987, Methods for the determination of organic substances in water and fluvial sediments: Techniques of Water-Resources Investigations of the United States Geological Survey, Book 5, Chapter A3, 80 p. 


\section{APPENDIX 1}

Periphyton analyses of sampling stations near Jackson, Tennessee 
32 
Appendix 1. Periphyton analyses of sampling stations near Jackson, Tennessee

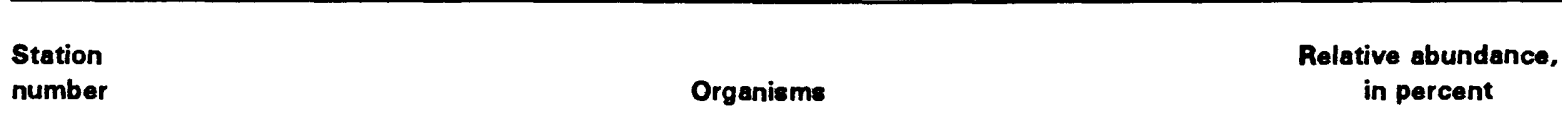

JC-01

BACILLARIOPHYTA (Diatoms)

Order Pennales

Achnanthes lanceolata $\quad 2.98$

Achnanthes linearis $\quad 3.25$

Achnanthes minutissima $\quad 7.58$

Amphora perpusilla $\quad 1.62$

Fragilaria brevistriata $\quad 1.08$

Navicula arvensis $\quad 2.71$

Navicula gottlandica $\quad 1.62$

Navicula mutica $\quad 1.90$

Nitzschia acicularis $\quad 1.90$

Nitzschia frustulum $\quad 3.25$

Nitzschia lanceolata $\quad 5.15$

Nitzschia palea $\quad 10.29$

Nitzschia sigma var. clausii $\quad 5.69$

Nitzschia sp. $\quad 2.98$

Surirella ovalis $\quad .54$

Synedra rumpens $\quad 4.60$

CHLOROPHYTA (Green algae)

Chlorella sp. $\quad 1.48$

Chlorococcum sp. $\quad 4.43$

Coleochaetae sp. $\quad 6.90$

Scenedesmus armatus $\quad 1.97$

CYANOPHYTA (Blue-green algae)

Lyngbya diguettii $\quad 10.84$

Lyngbya sp. $\quad 5.91$

Oscillatoria formosa $\quad 5.42$

Synechococcus sp. $\quad 5.91$

AB-02

BACILLARIOPHYTA (Diatoms)

Order Pennales

Achnathes lanceolata $\quad 2.23$

Achnathes linearis $\quad 2.23$

Achnanthes minutissima $\quad 6.69$

Amphora perpusilla $\quad 2.23$

Cymbella pusilla

Fragilaria brevistriata $\quad 2.23$

Fragilaria crotenensis $\quad 3.34$

Gomphonema parvulum $\quad 1.11$

Navicula arvensis $\quad 5.57$

Navicula mutica $\quad 11.14$

Nitzschia Hantzschiana $\quad 2.23$

Nitzschia lanceolata $\quad 2.23$ 
Appendix 1. Periphyton analyses of sampling stations near Jackson, Tennessee--Continued

Station

number

Organisms

Relative abundance,

in percent

AB- 02

BACILLARIOPHYTA (Diatoms)--Continued

Order Pennales

Nitzschia palea

4.46

Nitzschia sigma var. clausii

1.11

Nitzschia sp.

2.23

Stauroneis anceps

2.23

Surirella didyma

3.34

Surirella ovalis

1.11

CHLOROPHYTA (Green algae)

Chlorococcum sp.

CYANOPHYTA (Blue-green algae)

Lyngbya diguetii

10.97

Lyngbya sp.

11.96

Oscillatoria angustissima

Oscillatoria formosa

5.32

Oscillatoria sp.

12.63

Synechococcus sp.

CC-03

BACILLARIOPHYTA (Diatoms)

Order Pennales

Achnanthes minutissima

9.46

Gomphonema parvulum

14.19

Navicula arvensis

4.73

CHLOROPHYTA (Green algae)

Chlorella sp.

8.92

Chlorococcum sp.

2.70

Coleochaetae sp.

CYANOPHYTA (Blue-green algae)

Calothrix sp.

Lyngbya digueti

Oscillatoria sp.

8.92

Phormidium tenue

Synechococcus sp.

CC-04

BACILLARIOPHYTA (Diatoms)

Order Pennales

Achnanthes lanceolata

Achnanthes linearis

Achnanthes minutissima

Eunotia sp.

Gomphonema parvulum 
Appendix 1. Periphyton analyses of sampling stations near Jackson, Tennessee--Continued

\begin{tabular}{|c|c|c|}
\hline $\begin{array}{l}\text { Station } \\
\text { number }\end{array}$ & Organisms & $\begin{array}{c}\text { Relative abundance, } \\
\text { in percent }\end{array}$ \\
\hline
\end{tabular}

CC-04

BACILLARIOPHYTA (Diatoms)--Continued

Order Pennales

Navicula arvensis

Navicula cryptocephala var. veneta $\quad 8.98$

Navicula mutica

4.01

Navicula pusilla $\quad .57$

Nitzschia filiformis $\quad .38$

Nitzschia frustulum $\quad .76$

Nitzschia Hantzschiana $\quad 1.72$

Nitzschia lanceolata $\quad .38$

Nitzschia palea $\quad 3.06$

Nitzschia sigma var. clausii $\quad .19$

Stauroneis anceps $\quad .19$

Surirella didyma $\quad 1.15$

Surirella ovalis $\quad .19$

CHLOROPHYTA (Green algae)

Chlorella sp.

Chlorococcum sp.

CYANOPHYTA (Blue-green algae)

Oscillatoria formosa $\quad 22.68$

Oscillatoria limosa $\quad 5.43$

Oscillatoria sp. $\quad 5.75$

Phormidium tenue $\quad 6.39$

Synechococcus sp. $\quad 10.54$

BACILLARIOPHYTA (Diatoms)

Order Centrales

Melosira varians

Order Pennales

Achnanthes lanceolata $\quad 2.30$

Achnanthes linearis $\quad 9.33$

Achnanthes minutissima $\quad 4.46$

Amphora perpusilla $\quad .54$

Cocconeis placentula var. euglypta $\quad .81$

Cymbella pusilla $\quad .13$

Gomphonema parvulum $\quad 2.57$

Navicula arvensis $\quad 1.89$

Navicula cryptocephala var. veneta $\quad 6.49$

Navicula gottlandica $\quad 2.17$

Navicula mutica $\quad .54$

Navicula pusilla $\quad .27$

Navicula rhynchocephala $\quad .40$

Nitzschia filiformis $\quad .27$ 
Appendix 1. Periphyton analyses of sampling stations near Jackson, Tennessee--Continued

Station

number
Oranisms
Relative abundance, in percent

CC-05

BACILLARIOPHYTA (Diatoms)--Continued

Order Pennales

$\begin{array}{lr}\text { Nitzschia frustulum } & .95 \\ \text { Nitzschia Hantzschiana } & 2.30 \\ \text { Nitzschia lanceolata } & .40 \\ \text { Nitzschia palea } & 1.49 \\ \text { Nitzschia sigma var. clausii } & 2.57 \\ \text { Surirella didyma } & 1.35 \\ \text { Surirella ovalis } & .27 \\ \text { Tabellaria fenestrata } & 1.62\end{array}$

CHLOROPHYTA (Green algae)

Chlamydomonas sp.

Chlorella sp.

4.79

Chlorococcum sp.

5.43

Oocystis pusilla

1.28

CYANOPHYTA (Blue-green algae)

Oscillatoria formosa

Oscillatoria limosa

7.99

Oscillatoria sp.

3.83

Phormidium tenue

13.10

Synechoccus sp.

5.75

CC-06

BACILLARIOPHYTA (Diatoms)

Order Centrales

Cyclotella sp. .16

Melosira distans

Order Pennales

Achnanthes linearis

Achnanthes minutissima

Amphora perpusilla

Fragilaria crotonensis

Gomphonema parvulum

Navicula arvensis

veneta

Navicula gottlandica

Navicula rhynchocephala

Nitzschia Hantzschiana

Nitzschia lanceolata

Nitzschia palea

Nitzschia sigma

Nitzschia sigma var. clausii 
Appendix 1. Periphyton analyses of sampling stations near Jackson, Tennessee--Continued

Station
number Organisms $\quad \begin{gathered}\text { Relative abundance, } \\ \text { in percent }\end{gathered}$

$\mathrm{CC}-06$

BACILLARIOPHYTA (Diatoms)--Continued

Order Pennales

Stauroneis anceps $\quad .28$

Surirella didyma $\quad .14$

$\begin{array}{ll}\text { Synedra ulna var. ramesi } & .97\end{array}$

CHLOROPHYTA (Green algae)

Chlorella sp.

4.66

Chlorococcum sp.

4.32

Scenedesmus bijuga

1.00

CYANOPHYTA (Blue-green algae)

Dactylococcopsis fascicularis $\quad 19.63$

Oscillatoria angustissima $\quad 5.98$

Oscillatoria formosa $\quad 1.66$

Oscillatoria sp. $\quad 9.98$

Phormidium tenue $\quad 37.93$

Synechococcus sp. $\quad 3.33$

\section{CRYPTOPHYTA}

Cryptomonas erosa

FD-07

BACILLARIOPHYTA (Diatoms)

Order Centrales

Cyclotella meneghiniana

Melosira varians

Order Pennales

Achnanthes lanceolata $\quad .11$

Achnanthes linearis $\quad 1.65$

Achnanthes minutissima $\quad 1.54$

Amphora perpusilla $\quad .11$

Cymbella pusilla $\quad .11$

Epithemia sp. $\quad .22$

Gomphonema parvulum $\quad .33$

Navicula arvensis $\quad 1.54$

Navicula cryptocephala var. veneta $\quad .55$

Navicula mutica $\quad .88$

Navicula pusilla $\quad 1.65$

Navicula rhynchocephala $\quad .44$

Nitzschia acicularis $\quad .11$

Nitzschia frustulum $\quad .33$

Nitzschia Hantzschiana $\quad .44$

Nitzschia lanceolata $\quad .22$

Nitzschia palea $\quad .88$

Nitzschia parvula $\quad .11$ 
Appendix 1. Periphyton analyses of sampling stations near Jackson, Tennessee--Continued

Station

number
Organisms
Relative abundance,

in percent

FD-07

BACILLARIOPHYTA (Diatoms)--Continued

Order Pennales

Nitzschia sigma var. clausii $\quad 1.10$

Pinnularia biceps $\quad .22$

Stauroneis anceps $\quad .33$

Surirella didyma $\quad .11$

Surirella ovalis $\quad .11$

Synedra ulna $\quad .11$

Synedra ulna var. ramesi $\quad .44$

CHLOROPHYTA (Green algae)

Chlorella sp.

Chlorococcum sp.

CYANOPHYTA (Blue-green algae)

Dactylococcopsis fascicularis $\quad 6.15$

Lyngbya sp. $\quad .27$

Oscillatoria angustissima $\quad 8.29$

Oscillatoria formosa $\quad 5.88$

Oscillatoria sp. $\quad 14.16$

Phormidium tenue $\quad 14.43$

Schizothrix sp. $\quad 5.61$

Synechococcus sp. $\quad 15.51$

\section{CRYPTOPHYTA}

Cryptomonas erosa

FD-08

BACILLARIOPHYTA (Diatoms)

Order Centrales

Cyclotella sp.

Melosira varians

Order Pennales

$\begin{array}{lr}\text { Achnanthes lanceolata } & .37 \\ \text { Achnanthes linearis } & 2.57\end{array}$

Achnanthes minutissima $\quad 1.47$

Amphora veneta $\quad .55$

Cocconeis placentula var. euglypta $\quad .92$

Cymbella pusilla $\quad .73$

Gomphonema parvulum $\quad 2.94$

Gyrosigma acuminatim $\quad .55$

Navicula arvensis $\quad 3.48$

Navicula cryptocephala var. veneta $\quad 1.65$

Navicula gottlandica $\quad .73$

Navicula mutica $\quad 4.04$

Navicula pusilla $\quad .73$

Navicula secreta var. apiculata $\quad 1.28$

38 Water Quality, Organic Chemistry of Sediment, and Biological Conditions of Streams

Near an Abandoned Wood-Preserving Plant Site at Jackson. Tennessee 
Appendix 1. Periphyton analyses of sampling stations near Jackson, Tennessee--Continued

Station

number
Organisms
Relative abundance.

in percent

FD-08

BACILLARIOPHYTA (Diatoms)--Continued

Order Pennales

Nitzschia acicularis

1.10

Nitzschia filiformis

.18

Nitzschia frustulum

2.94

Nitzschia Hantzschiana

3.30

Nitzschia laevissima

Nitzschia lanceolata

Nitzschia palea

Nitzschia sigma

1.47

Nitzschia sigma var. clausii

4.95

Pinnularia sp.

Surirella didyma

Surirella linearis

Surirella ovalis

Synedra ulna var. ramesi

CHLOROPHYTA (Green algae)

Chlorella sp.

Chlorococcum sp.

CYANOPHYTA (Blue-green algae)

Dactylococcopsis fascicularis

Oscillatoria formosa

Oscillatoria sp.

14.38

Phormidium tenue

8.06

Stigonema sp.

9.60

Synechococcus sp.

3.46

\section{CRYPTOPHYTA}

Cryptomonas erosa

FD-09

BACILLARIOPHYTA (Diatoms)

Order Centrales

Cyclotella sp.

Melosira distans

1.03

Melosira varians

1.03

Order Pennales

$\begin{array}{ll}\text { Achnanthes lanceolata } & .66 \\ \text { Achnanthes linearis } & .66\end{array}$

Achnanthes minutissima $\quad .88$

Cocconeis placentula var. euglypta $\quad .66$

Cymbella tumida $\quad .22$

Cymbella pusilla $\quad .88$

Eunotia arcus $\quad .22$

Gomphonema parvulum $\quad 1.76$ 
Appendix 1. Periphyton analyses of sampling stations near Jackson, Tennessee--Continued

Station

number
Organisms
Relative abundance,

in percent

FD-09

BACILLARIOPHYTA (Diatoms)--Continued

Order Pennales

Navicula arvensis

.45

Navicula cryptocephala var. veneta

1.10

Navicula mutica

.88

Navicula pusilla

1.32

Navicula rhynchocephala

.45

Navicula secreta var. apiculata

1.10

Nitzschia acicularis

.66

Nitzschia frustulum

2.86

Nitzschia Hantzschiana

1.32

Nitzschia lanceolata

Nitzschia palea

2.20

Nitzschia sigma var. clausii

Pinnularia biceps

Pinnularia sp.

1.10

Surirella didyma

.66

Surirella linearis

1.10

Synedra acus

Synedra delicatissima

CHLOROPHYTA (Green algae)

Chlamydomonas sp.

1.46

Chlorella sp.

10.22

Chlorococcum sp.

CYANOPHYTA (Blue-green algae)

Oscillatoria angustissima

Oscillatoria sp.

Phormidium tenue

Stigonema sp.

2.92

Synechococcus sp. 


\section{APPENDIX 2}

Benthos and fish inventory for sampling stations near Jackson, Tennessee 
42 
Station number: JC-01

Date: December 12, 1990

Width at riffle: $2.4-3$ meters

Average velocities and depths: 30.5 centimeters per second; 33.5 centimeters

16.3 centimeters per second; 25.9 centimeters

15.2 centimeters per second; 13.7 centimeters

Substrate: Sand, some gravel.

\section{BENTHOS}

No. organisms collected

ODONATA

Gomphidae

Dromogomphus nr. spinosus

\section{MEGALOPTERA}

Sialidae

Sialis sp.

\section{DIPTERA}

Tipulidae

Tipula sp.

1

Chironomidae

Rheotanytarsus sp.

6

\section{CRUSTACEA - DECAPODA}

Astacidae

Procambarus nr. ablusus

\section{GASTROPODA}

Physidae

Physa sp.

\section{PELECYPODA \\ Sphaeriidae}

Pisidium sp.

\section{OLIGOCHAETA}

Naididae

Nais sp.

FISH

Petromyzontidae

Ichthyomyzon gagei (Southern brook lamprey)

Esocidae

Esox niger (Chain pickerel)

2

Cyprinidae

Notropis boops (Bigeye shiner)

46

Pimephales notatus (Bluntnose minnow)

6

Fundulidae

Fundulus olivaceus (Blackspotted topminnow)

2 
Appendix 2. Benthos and fish inventory for sampling stations near Jackson, Tennessee--Continued

FISH (JC-01)-Continued

No. organisms collected

Centrarchidae

Lepomis cyanellus (Green sunfish)

Micropterus dolomeiui (Smallmouth bass)

1

Percidae

Etheostoma flabellare (Fantail darter)

1

Etheostoma nigrum (Johnny darter)

1

Etheostoma zonale (Banded darter)

6

9

Station number: $\mathrm{AB}-02$

Date: December 11, 1990

Width at riffle: 4.7 meters

Average velocities and depths: 17.3 centimeters per second; 19.8 centimeters

0.9 centimeters per second; 21.3 centimeters

108.9 centimeters per second; 15.2 centimeters

Substrate: 50 percent large cobble/boulder/sand

\section{BENTHOS}

No. organisms collected

\section{ODONATA}

Gomphidae

Progomphus obscurus

1

\section{CRUSTACEA - DECAPODA}

Astacidae

Cambarus sp.

\section{OLIGOCHAETA}

Naididae

Nais sp.

FISH

Cyprinidae

Notropis boops (Bigeye shiner)

Semotilus atromaculatus (Creek Chub)

4

Catostomidae

Carpiodes carpio (River carpsucker)

4

Poeciliidae

Gambusia affinis (Mosquitofish)

1

Ictaluridae

Ameiurus natalis (Yellow bullhead)

1

Centrarchidae

Lepomis cyanellus (Green Sunfish) 
Appendix 2. Benthos and fish inventory for sampling stations near Jackson, Tennessee--Continued

Station number: $\mathrm{CC}-03$

Date: December 10, 1990

Width at riffle: 1.22 meters (varying to 2 meters)

Average velocities and depths: 33.5 centimeters per second; 6.1 centimeters

2.03 centimeters per second; 12.2 centimeters

2.03 centimeters per second; 7.6 centimeters

Substrate: Small cobble/gravel (riffles)

gravel/sand (pools)

\section{BENTHOS}

No. organisms collected

\section{EPHEMEROPTERA}

Oligoneuriidae

Isonychia sp.

Heptageniidae

Stenonema sp.

\section{DIPTERA}

Chironomidae

Chironomus sp.

\section{OLIGOCHAETA}

Naididae

Nais sp.

FISH

Cyprinidae

Semotilus atromaculatus (Creek Chub)

Poeciliidae

Gambusia affinis (Mosquitofish)

Centrarchidae

Lepomis cyanellus (Green Sunfish)

Station number: CC-04

Date: December 12, 1990

Width at riffle: 1.22 meters

Average velocities and depths: 26.4 centimeters per second; 6.1 centimeters

17.3 centimeters per second; 18.3 centimeters

10.2 centimeters per second; 24.4 centimeters

Substrate: Medium cobble/gravel/25 percent sand

\section{BENTHOS}

No. organisms collected

\section{ODONATA}

Coenagrionidae

Chromagrion sp. 
Appendix 2. Benthos and fish inventory for sampling stations near Jackson, Tennessee--Continued

BENTHOS (CC-04)--Continued

No. organisms collected

\section{DIPTERA}

Chironomidae

Chironomus sp.

Syrphidae

Eristalis nr. tenax

\section{GASTROPODA}

Physidae

Physa sp.

\section{OLIGOCHAETA}

Lumbricidae

Eiseniella tetraedra

Naididae

Nais sp.

FISH

Cyprinidae

Notemigonus crysoleucas (Golden shiner)

Fundulidae

Fundulus olivaceus (Blackspotted topminnow)

Poeciliidae

Gambusia affinis (Mosquitofish)

Centrarchidae

Lepomis cyanellus (Green sunfish)

6

Micropterus dolomieui (Smallmouth bass)

Station number: CC-05

Date: December 11, 1990

Width at riffle: 1.22 meters

Average velocities and depths: 13.2 centimeters per second; 6.1 centimeters

5.08 centimeters per second; 24.4 centimeters

2.03 centimeters per second; 33.5 centimeters

Substrate: Sand and some small patches of gravel

\section{BENTHOS}

No. organisms collected

\section{ODONATA}

Coenagrionidae

Chromagrion sp.

Libellulidae

Plathemis lydia

DIPTERA

Chironomidae

Chironomus sp. 
Appendix 2. Benthos and fish inventory for sampling stations near Jackson, Tennessee--Continued

BENTHOS (CC-05)--Continued

GASTROPODA

No. organisms collected

Physidae

Physa sp.

17

\section{OLIGOCHAETA}

Lumbricidae

Eiseniella tetraedra

3

Naididae

Nais sp.

FISH

Fundulidae

Fundulus olivaceus (Blackspotted topminnow) $\quad 1$

Poeciliidae

Gambusia affinis (Mosquitofish)

9

Centrarchidae

Lepomis cyanellus (Green sunfish)

3

Percidae

Etheostoma flabellare (Fantail darter)

1

Station number: $\mathrm{CC}-06$

Date: December 11, 1990

Width at riffle: 3.05 meters

Average velocities and depths: 2.03 centimeters per second; 24.4 centimeters

25.4 centimeters per second; 6.1 centimeters

18.3 centimeters per second; 9.1 centimeters

Substrate: Sand (oily sheen on sand and water surface)

\section{BENTHOS}

No. organisms collected

\section{ODONATA}

Coenagrionidae

Chromagrion sp.

Libellulidae

Plathemis lydia

1

\section{DIPTERA}

Chironomidae

Chironomus sp.

\section{OLIGOCHAETA}

Naididae

Nais sp. 
Appendix 2. Benthos and fish inventory for sampling stations near Jackson, Tennessee--Continued

FISH (CC-06)

No. organisms collected

Ictaluridae

Ictalurus natalis (Yellow bullhead)

1

Poeciliidae

Gambusia affinis (Mosquitofish)

8

Centrarchidae

Lepomis cyanellus (Green sunfish)

Station number: FD-07

Date: December 12, 1990

Width: 30 meters

Average velocities and depths: 29.5 centimeters per second; 36.6 centimeters

11.2 centimeters per second; 21.3 centimeters

0.0 centimeters per second; 30.5 centimeters

Substrate: Sand, silt, isolated gravel

Date: December 12, 1990

BENTHOS

No. organisms collected

\begin{abstract}
EPHEMEROPTERA
Leptophlebiidae

Leptophlebia cupida

Heptageniidae

Stenonema nepotellum 2

\section{PLECOPTERA}

Taeniopterygidae

$\begin{array}{ll}\text { Taeniopteryx burksi } & 21\end{array}$

\section{OLIGOCHAETA}

Naididae

Nais sp.

FISH

Cyprinidae

Notropis spilopterus (spotfin shiner)

Ictaluridae

Ameiurus nebulosus (Brown bullhead) $\quad 4$

Poeciliidae

Gambusia affinis (Mosquitofish)

Centrarchidae

Lepomis cyanellus (green sunfish) 2

Lepomis macrochirus (bluegill) $\quad 3$ 
Appendix 2. Benthos and fish inventory for sampling stations near Jackson, Tennessee--Continued

Station number: FD-08

Date: December 11, 1990

Width: 30 meters (riffle/run)

Average velocities and depths: 31.5 centimeters per second; 15.2 centimeters

15.2 centimeters per second; 36.6 centimeters

8.1 centimeters per second; 45.7 centimeters

Substrate: Sand, isolated snags

\section{BENTHOS}

No. organisms collected

EPHEMEROPTERA

Oligoneuriidae

Isonychia sp.

Heptageniidae

Stenonema nepotellum

6

Leptophlebiidae

Leptophlebia cupida

7

\section{PLECOPTERA}

Taeniopterygidae

Taeniopteryx burksi

\section{TRICHOPTERA}

Limnephilidae

Hydatophylax argus

\section{DIPTERA}

Chironomidae

Pentaneura sp.

Parametriocnemus sp.

Phaenopsectra flavipes

3

Brillia $n$ r. flavifrons

\section{OLIGOCHAETA}

\section{Naididae}

Nais sp.

FISH

Ictaluridae

Ameiurus nebulosus (Brown bullhead)

Fundulidae

Fundulus olivaceus (Blackspotted topminnow)

Poeciliidae

Gambusia affinis (Mosquitofish)

4

Centrarchidae

Lepomis cyanellus (Green sunfish)

1 
Appendix 2. Benthos and fish inventory for sampling stations near Jackson, Tennessee--Continued

Station number: FD-09

Average velocities, depths: 30.5 centiuneters per second, 33.5 centimeters

Date: Decennber 12, 1990

15.2 centimeters per second, 24.4 centimeters

(more than 90 percent of area over 1 meter deep)

Substrate: Sand and silt

\section{BENTHOS}

No. organisms collected

EPHEMEROPTERA

Baetidae

Baetis sp.

1

Tricorythidae

Tricorythodes sp.

4

Leptophlebiidae

Leptophlebia cupida

Heptageniidae

Stenonema nepotellum

2

ODONATA

Gomphidae

Dromogomphus nr. spinosus

PLECOPTERA

Taeniopterygidae

Taeniopteryx burksi

TRICHOPTERA

Hydropsychidae

Hydropsyche sp.

CRUSTACEA - DECAPODA

Astacidae

Procambarus nr. ablusus

\section{FISH}

No fish collected 